Original paper

\title{
Petrology and age of metamorphosed rocks in tectonic slices inside the Palaeozoic sediments of the eastern Mongolian Altay, SW Mongolia
}

\author{
Kristýna HRDLIČKOVÁ ${ }^{*}$, Khasbazaar BOLORMAA², David BURIÁNEK¹, Pavel HANŽL', \\ Axel GERDES ${ }^{3}$, Vojtěch JANOUŠEK ${ }^{1}$
}

${ }^{1}$ Czech Geological Survey, Klárov 3, 11821 Prague 1, Czech Republic; kristyna.hrdlickova@geology.cz

${ }^{2}$ Geological Investigation Centre, Songino Khayrkhan District, PO Box 37/307, Ulaanbaatar, Mongolia; khasbolorma@yahoo.com

${ }^{3}$ Institut für Geowissenschaften, J. W. Goethe Universität, Altenhöferallee 1; 60438 Frankfurt am Main; Germany; gerdes@em.uni-frankfurt.de

* Corresponding author

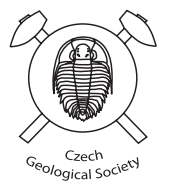

\begin{abstract}
Three crystalline complexes were newly described in the area of the junction between the Mongolian Altay and Gobi Altay in the surroundings of Chandman Sum, SW Mongolia. Khan Khayrkhan, Chandman Khayrkhan and Unegt Uul crystalline complexes were distinguished on the basis of their geological position, distinct petrography, metamorphic style and contrasting geochronological data. These units are situated along the northern margin of the Gobi-Altay Terrane and at first sight seem to have a very simple and uniform history. However, detailed studies reveal a more complex and varied evolution.

The Unegt Uul Crystalline Complex is a tectonic mélange of leucogranites, amphibolites and mica schists exposed between the branch of the Bogd fault in the north and Lower Palaeozoic sediments in the south. Metamorphic rocks suffered a prograde metamorphic event reaching temperatures of c. $650{ }^{\circ} \mathrm{C}$ and pressures of $6-7.5 \mathrm{kbar}$ estimated from amphibolites. This Complex represents the oldest of the three units; the age of leucogranite formation corresponds to Cambrian $(518 \pm 5 \mathrm{Ma})$

Chandman Khayrkhan Crystalline Complex is also restricted by Bogd fault from the north but southern boundary is limited by an intrusive contact with the Chandman Massif. It is composed of orthogneisses and migmatites with amphibolite and calc-silicate lenses. The Complex was affected by a HT, likely periplutonic, metamorphic event and subsequent retrogression. While the rocks of the Chandman Khayrkhan Crystalline Complex remain undated, the age of the granitic rocks in the Chandman Massif itself are Early Carboniferous ( $345 \pm 2 \mathrm{Ma}$ ).

The Khan Khayrkhan Crystalline Complex has tectonic contacts with the surrounding Palaeozoic volcanosedimentary units. It is built by orthogneisses, amphibolites, paragneisses and mica schists. Metamorphic style corresponds to a prograde event with peak at $c .670{ }^{\circ} \mathrm{C}$ and $7-10 \mathrm{kbar}$. The crystallization age for the granitic protolith to the orthogneisses was the latest Devonian $(363 \pm 3 \mathrm{Ma})$.
\end{abstract}

Keywords: Variscan metamorphism, $P-T$ calculations, ICP-MS, U-Pb zircon dating, Mongolian Altay, Gobi Altay Terrane Received: 4 April 2008; accepted 2 July 2008; handling editor: W.S. Faryad

The online version of this article (doi: 10.3190/jgeosci.027) contains supplementary electronic material.

\section{Introduction}

Generally speaking, there is lack of data on conditions and timing of metamorphism in Mongolia and the SW part of the country is no exception. In contrast, numerous works have been concerned with Cenozoic faults (e.g. Molnar and Tapponnier 1975; Bayasgalan et al. 1999; Cunningham et al. 2003; Vassallo et al. 2007) as well as Palaeozoic (Dergunov 2001 or Windley et al. 2007 for review) or Mesozoic (e. g. Yarmolyuk and Kovalenko 2001) volcanosedimentary complexes. Geochronological data and tectonostratigraphic reconstructions have been assembled recently for the region of south-western
Mongolia (Kepezhinskas et al. 1991; Badarch and Tomurtogoo 2001; Badarch et al. 2002; Buchan et al. 2002; Khain et al. 2002, 2003; Kovach et al. 2005; Kozakov et al. 2005; Helo et al. 2006).

Traditionally, the territory of Mongolia has been subdivided into northern and southern domains, which are separated by the so-called Main Mongolian lineament - a regional topographic and structural boundary dividing mostly Precambrian and Lower Palaeozoic rocks in the north from dominantly Middle-Upper Palaeozoic units in the south (Marinov et al. 1973; Badarch et al. 2002). The studied area is situated right along this boundary, which separates here the two different structural zones, the Lake 
Zone in the north and the Gobi Altay Zone in the south (Rauzer et al. 1987). The Lake Terrane represents, according to Badarch et al. (2002) a former island arc and Gobi Altay Terrane is interpreted as a backarc/forearc basin.

Metamorphic domains are insufficiently known in the Mongolian and Gobi Altay mountain ranges. New metamorphic complexes were described during the geological survey of Zamtyn Nuruu area (Hanžl and Aichler 2007; see Introduction to this Volume), where the south-eastern Mongolian Altay and eastern Gobi-Altay ranges merge south of the Bogd fault in the Gichigeney Nuruu and Bayan Tsagaan Mts. These Unegt Uul (UUC), Chandman Khayrkhan (CHC) and Khan Khayrkhan (KKC) crystalline complexes recorded medium- to high-temperature and medium-pressure conditions. This paper brings first petrologic and $\mathrm{P}-\mathrm{T}$ data from the metamorphic rocks in the western part of the Gobi-Altay Terrane, complemented by geochemical and isotopic analyses as well as $\mathrm{U}-\mathrm{Pb}$ zircon and monazite dating.

\section{Geological setting}

The studied region is situated in the SW Mongolia, approximately $740 \mathrm{~km} \mathrm{SW}$ of Ulaanbaatar at the junction of south-eastern Mongolian Altay (Gichigeney Nuruu range) with eastern Gobi Altay (eastern Bayan Tsagaan range represented by Unegt Uul and Chandman Uul).

Geologically, Mongolia is built by a number of tectonic zones that form the part of the extensive Central Asian Orogenic Belt - CAOB (Mossakovsky et al. 1994) known also as Altaids (Sengör et al. 1993). This belt has developed between the Siberian Block in the north, the Tarim Block in the south-west and the Sino-Korean Block in the south. It is characterized by an accretion of various terranes of different origin (Sengör et al. 1993; Windley et al. 2002; Jahn et al. 2004) and evolved during time span of 1000-250 Ma (Windley et al. 2007). Nevertheless, the tectonic evolution of the CAOB in north-eastern Mongolia culminated during the closure of

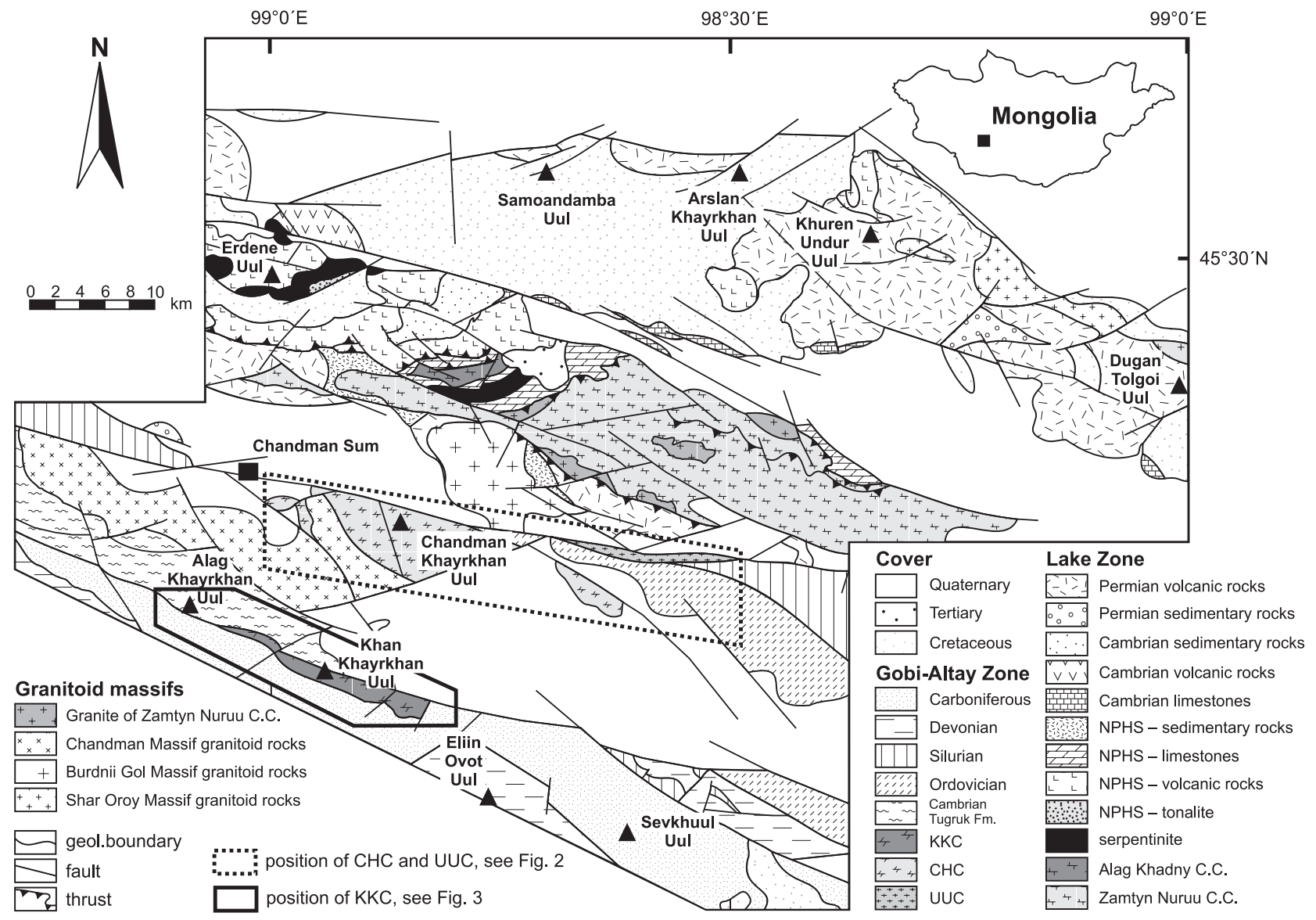

Fig. 1 Geological outline of the studied area in the easternmost Mongolian Altay (based on Hanžl and Aichler 2007 and results presented in this Volume). KKC - Khan Khayrkhan Crystalline Complex; CHC - Chandman Khayrkhan Crystalline Complex; UUC - Unegt Uul Crystalline Complex, NPHS - Khan Taishir Fm. 
the Mongolian-Okhotsk marine basin in Early Jurassic times (Yarmolyuk and Kovalenko 2001).

The studied area is a part of the Gobi-Altay domain of the Altay orogen extending eastward from Russia and eastern Kazakhstan, through the northern China to southwestern Mongolia. The Gobi-Altay Terrane most likely represents the south-western continental margin of the Siberian Plate (Xiao et al. 1992). According to Badarch et al. (2002), it forms a long narrow belt rimming the northern margin of the southern domain of Mongolia. It is composed of Cambrian (?) marine sediments and volcanoclastic rocks metamorphosed under greenschist-facies conditions accompanied by Palaeozoic sediments, with volcanic and volcanoclastic rocks of a forearc/backarc character. The sequence was intruded mainly by Carboniferous to Permian granite plutons.

Three metamorphic units were recognized in the eastern part of the Gobi-Altay Terrane in a form of tectonic slices inside the Palaeozoic sediments and volcanoclastic rocks. The Chandman Khayrkhan and Unegt Uul crystalline complexes are exposed in the easternmost range of the Bayan Tsagaan Mts. and the Khan Khayrkhan Crystalline Complex on the NE slopes of the Gichigeney Nuruu Mts. (Fig. 1).

\subsection{Unegt Uul Crystalline Complex (UUC)}

The exposures of UUC are restricted to a narrow belt in the Unegt Uul range lying directly in the tectonic mélange of the Bogd fault zone (Hanžl and Aichler 2007) (Fig. 2). The E-W trending branches of the master fault separate crystalline rocks and Permian volcanic rocks in the north from the Lower Palaeozoic marine sediments with limestone layers in the south. The rocks of UUC are represented mainly by deformed and metamorphosed biotite granites to leucogranites, aplitic granites and pegmatites. Gneisses, mica schists and amphibolites represent roof pendants of the granitic intrusions. Lenses of gabbros, ultramafic rocks, amphibolites and undifferentiated sediments are parts of a tectonic mélange in the eastern part of the belt.

Structural characteristics of the Unegt Uul Crystalline Complex reflect large-scale tectonic processes of brittle character. The $\mathrm{E}-\mathrm{W}$ oriented fragmental faults of the Bogd fault system are the most distinct features. Faults are commonly accompanied by tens to a few hundred meters wide mylonitic zones of anastomozing character. Furthermore, E-W elongated Unegt Uul Crystalline Complex is transversely segmented by several NW-SE trending faults.

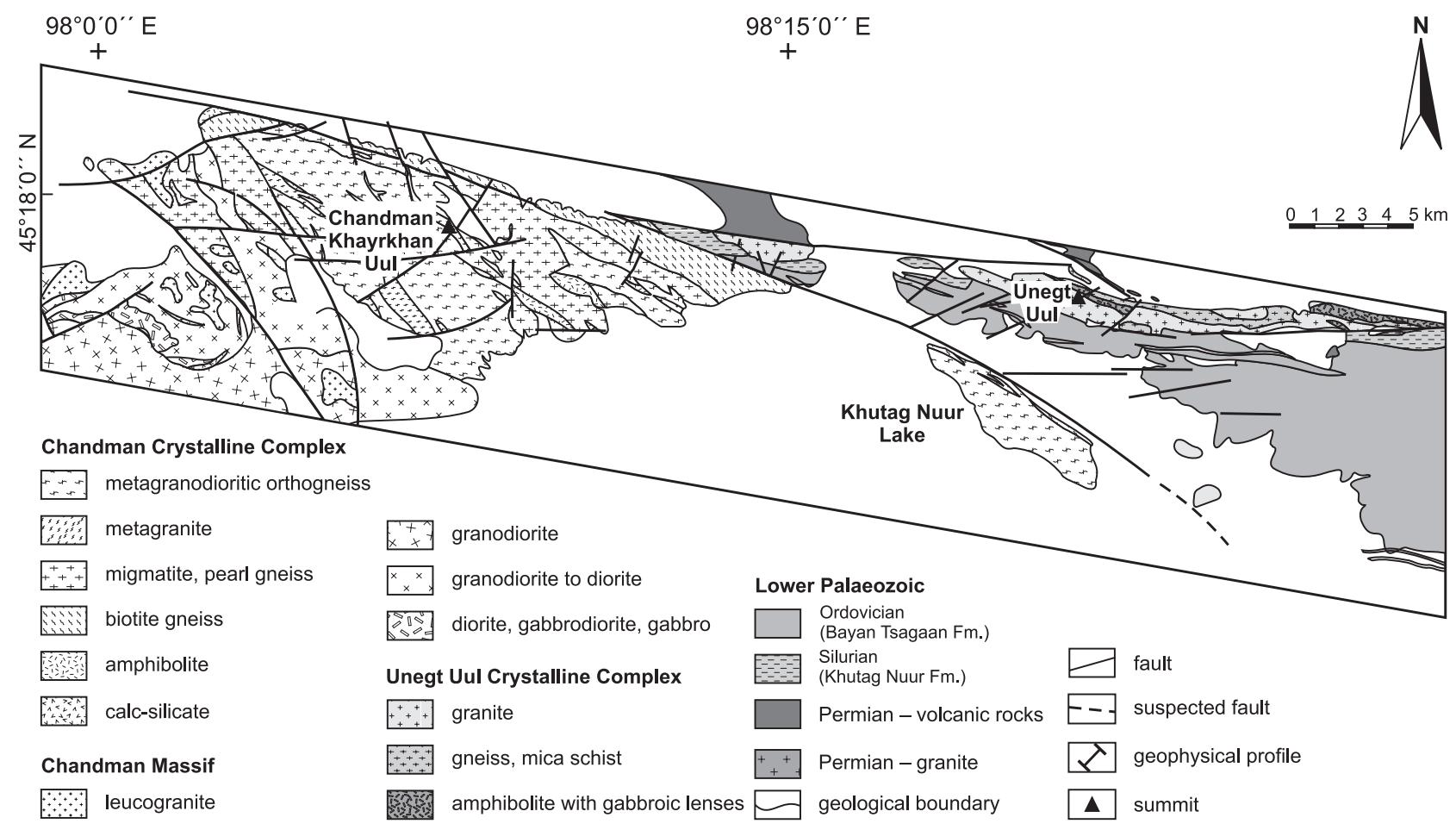

Fig. 2 More detailed geological map of the Chandman Khayrkhan and Unegt Uul crystalline complexes. 
Ductile fabrics are represented by foliation and lineation in gneisses and amphibolites preserved as roof pendants to cataclastic granites. Subvertical tight folds with E-W trending axes are rare. Foliations are NW-SE trending with dips varying from $30-65^{\circ}$ to $\mathrm{NE}$ or SW. Lineations have a crenulation character in mica schists and plunge to SE under $20-40^{\circ}$ and are subparallel with fold axes.

\subsection{Chandman Khayrkhan Crystalline Complex $(\mathrm{CHC})$}

The $\mathrm{CHC}$ is situated in an $\mathrm{E}-\mathrm{W}$ trending belt between the Chandman Sum and Khutag Nuur lake (Figs 1-2). It is exposed in tectonic blocks lining the Bogd fault from the $\mathrm{S}$ in the area of the Chandman Khayrkhan Uul and one of its branches north of Khutag Nuur.

The northern border of $\mathrm{CHC}$ is formed by the scarp of the Chandman rupture (Baljinnyam et al. 1993) of the Bogd fault. Boudins of limestones and sediments of the Lower Palaeozoic formations exposed there emphasize the fault line. The metamorphic complex is limited in the SW by intrusive rocks of the Chandman Massif; the southern continuation is covered by Quaternary sediments.

Migmatites, gneisses and orthogneiss of granitic to granodioritic composition alternate in WNW-ESE oriented irregular stripes and lenses. Amphibolite and calc- silicate lenses are rare. Rocks are penetrated by numerous thin dykes of aplites and pegmatites (Buriánek et al. in press). The conspicuous NWN-ESE trending foliation is moderately to steeply dipping to the south. The foliation planes bear metamorphic lineations plunging variably to NW or SE. Towards the SW, the degree of deformation in orthogneisses decreases; rocks acquire an appearance of metagranitoids and pass gradually into granitic rocks of the Chandman Massif. Granitoids of the Chandman Massif intruded the high-grade metamorphic rocks and both units were subsequently jointly deformed. Therefore the $\mathrm{CHC}$ represents wall rocks to the intrusion, which fact is reflected by a number of (deformed) pegmatite dykes pertaining to Chandman Massif penetrating the $\mathrm{CHC}$.

\subsection{Khan Khayrkhan Crystalline Complex $(K K C)$}

The KKC is exposed as narrow, NW-SE trending tectonic slice along the NE slopes of the Gichigeney Nuruu range; the most extensive exposures are in the area of Khan Khayrkhan Uul (NW part of the Gichigeney Nuruu). The north-eastern as well as south-western boundary of this unit are formed by steep faults (Fig. 3). Carboniferous turbidites crop out in the SW, slightly metamorphosed volcanoclastic sediments of supposed Cambrian age (Rauzer et al. 1987) occur in the NE. A small tectonic slice of the

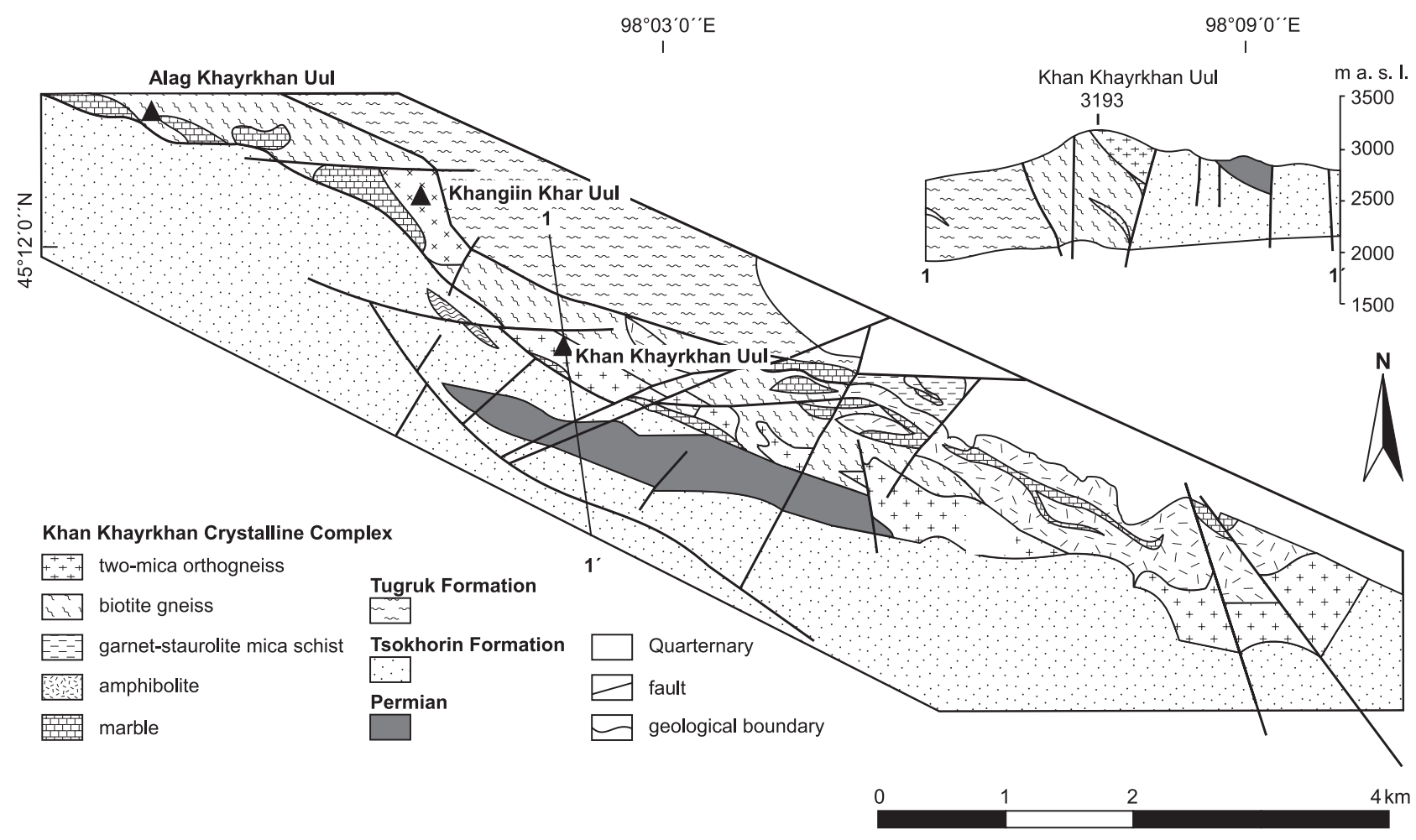

Fig. 3 More detailed geological map of the Khan Khayrkhan Crystalline Complex 
KKC mapped in the area of the Darkhan Uul at the southeastern termination of the mountain range is exposed between the Carboniferous turbidites and Devonian limestones. The $\mathrm{KKC}$ is characterised by varying lithologies. Fine-grained gneisses alternating with amphibolites occur on the NE slopes of the Khan Khayrkhan Uul. They are accompanied by intercalations of crystalline limestones and lenses of garnet-staurolite mica schists in the E part. The mountain range itself is built by fine- to mediumgrained two-mica orthogneisses. The contact between orthogneisses and amphibolites is concordant.

Structures are characterized by a dominant foliation, which is NW-SE striking and steeply dipping to NE and SW. It corresponds to folding by large steep and tight folds confirmed by geological mapping (Hanžl and Aichler 2007). Linear structural elements - fold axes as well as lineations - are subhorizontal with prevailing WNW-ESE orientation.

The recrystallized limestones of the KKC contain also relics of fossil material. However, the fossils are poorly preserved and their determination may be problematic. Still, Middle to Late Ordovician age may be with certain doubts supposed for the belt of strongly re-crystallised carbonates forming rock cliffs at the summit of the Khan Khayrkhan Uul. The age is based on the rare remains of the questionable Pluricollumnalia (crinoid possessing a rather Ordovician character but indeterminable because of fairly high degree of metamorphic overprint - determination made by R. Prokop from National Museum, Prague). Nevertheless, strongly recrystallized limestones to marbles locally contain perceptible but entirely indeterminable echinoderms - possibly crinoid debris. From the residuum after maceration (tectonically confined outcrop of limestones with cherts), questionable sponge spicules were found but their poor preservation prohibited an exact determination (Hanžl and Aichler 2007).

\section{Analytical techniques}

Electron microprobe analyses were performed in the Joint Laboratory of Electron Microscopy and Microanalysis of the Masaryk University and the Czech Geological Survey (Brno) on the Cameca SX-50 instrument. Operating conditions were $15 \mathrm{kV}$ accelerating voltage, and beam current of $80 \mathrm{nA}$. The obtained data were processed using THERMOCALC software (version 3.21; Powell and Holland, 1985; Holland and Powell, 1985; 1998; update February 2002) to calculate the P-T conditions and to reconstruct the metamorphic evolution of studied samples. Conventional thermometers (Thompson 1976; Lee and Holdaway 1977; Ferry and Spear 1978; Perchuk and Lavrent'eva 1983; Bhattacharya et al.1992; Ravna 2000) were also used for comparison.
Microprobe analyses for chemical Th-U-total Pb dating (CHIME) were carried out also in the Joint Laboratory of Electron Microscopy and Microanalysis in Brno. Operating conditions were $15 \mathrm{kV}$ accelerating voltage, beam current $80 \mathrm{nA}$ and a beam diameter of $<1 \mu \mathrm{m}$ for monazite and 5-10 $\mu \mathrm{m}$ for monazite alteration products. The monazite age was calculated using a method of Montel et al. (1996).

Isotope analyses for LA-ICP-MS (Laser Ablation-Inductive Coupled Plasma-Mass Spectrometry) U-Th- $\mathrm{Pb}$ dating of zircon and monazite were performed at the Institute of Geosciences, Goethe University Frankfurt, using a Thermo-Scientific Element II sector field ICP-MS coupled to a New Wave UP213 ultraviolet laser system (Gerdes and Zeh 2006, 2008). Laser spot-size varied from 20 to $40 \mu \mathrm{m}$ and spot-selection was guided by internal structures as seen in cathodoluminescence (CL) images of the mounted and polished grains. Data were acquired in peak jumping mode over 900 mass scans during 20s background measurements followed by 30 s sample ablation. A teardrop-shaped, low volume laser cell was used to enable precise detection of heterogeneous material during time resolved data acquisition. Raw data were corrected for background signal, common $\mathrm{Pb}$, laser induced elemental fractionation, instrumental mass discrimination, and time-dependant elemental fractionation of $\mathrm{Pb} / \mathrm{Th}$ and $\mathrm{Pb} / \mathrm{U}$ using an Excel spreadsheet.

For the $\mathrm{Sr}$ and $\mathrm{Nd}$ isotopic study, the samples were dissolved using a combined $\mathrm{HF}-\mathrm{HCl}-\mathrm{HNO}_{3}$ attack. Strontium was isolated by exchange chromatography techniques on PP columns with Sr.spec Eichrom resin and bulk REE were isolated on PP columns filled with TRU. spec Eichrom resin (Pin et al. 1994). The Nd was further separated on PP columns with Ln.spec Eichrom resin (Pin and Zalduegui 1997). Details of the procedure were published by Míková and Denková (2007). Isotopic analyses were performed on Finnigan MAT 262 thermal ionization mass spectrometer at Radiogenic Isotopes Laboratory of the Czech Geological Survey in dynamic mode using a double Re filament assembly. The ${ }^{143} \mathrm{Nd} /{ }^{144} \mathrm{Nd}$ ratios were corrected for mass fractionation to ${ }^{146} \mathrm{Nd} /{ }^{144} \mathrm{Nd}=0.7219$, ${ }^{87} \mathrm{Sr} /{ }^{86} \mathrm{Sr}$ ratios assuming ${ }^{86} \mathrm{Sr} /{ }^{88} \mathrm{Sr}=0.1194$. External reproducibility is given by results of repeat analyses of the La Jolla $\left({ }^{143} \mathrm{Nd} /{ }^{144} \mathrm{Nd}=0.511852 \pm 14(2 \sigma), \mathrm{n}=23\right)$ and NBS $987\left({ }^{87} \mathrm{Sr} /{ }^{86} \mathrm{Sr}=0.710247 \pm 26(2 \sigma), \mathrm{n}=25\right)$ isotopic standards. The $\mathrm{Rb}, \mathrm{Sr}, \mathrm{Sm}$ and Nd concentrations were obtained by ICP-MS in Acmelabs, Canada. The decay constants applied to age-correct the isotopic ratios were from Steiger and Jäger $(1977-\mathrm{Sr})$ and Lugmair and Marti $(1978-\mathrm{Nd})$. The initial $\varepsilon_{\mathrm{Nd}}$ values were obtained using Bulk Earth parameters of Jacobsen and Wasserburg (1980), the single- and two-stage Depleted Mantle Nd model ages $\left(\mathrm{T}_{\mathrm{Nd}}^{\mathrm{DM}}\right)$ were calculated after Liew and Hofmann (1988). 
Samples representing main lithological types at least 2-4 kg in weight were used for whole-rock geochemical analyses. Major and trace elements were determined at ACME laboratories, Canada. Total abundances of the major oxides were analysed by ICP-emission spectrometry following a lithium metaborate/tetraborate fusion and dilute nitric digestion. Loss on ignition (LOI) is the weight difference after ignition at $1000{ }^{\circ} \mathrm{C}$. The rare earth and most remaining trace elements were analysed by INAA and ICP-MS following a $\mathrm{LiBO}_{2}$ fusion; precious and base metals by aqua regia digestion/ICP-MS.

\section{Petrography}

\subsection{Unegt Uul Crystalline Complex}

Fine-grained biotite granites to leucogranites with muscovite and igneous garnet are accompanied by dykes/bodies of aplites and pegmatites and occupy much of the UUC. They are exposed as an E-W elongated body with length c. $10 \mathrm{~km}$ no more than $1 \mathrm{~km}$ wide. Rocks are often deformed and cataclased, which is evident from brittle deformation of feldspar grains and strong undulatory extinction of quartz. Gneisses, mica schists and amphibolites form metamorphic wall rocks of granites. They occur as xenoliths in granitoid rocks as well as lenses and belts lining the northern margin of the granite body. The thickness of the individual septa shows a considerable variation but usually does not exceed a few tens of metres.

Fine-grained amphibolites with lenses of metagabbros and serpentinites often occur along, or within, the metagranite body. They are exposed in the northern foothill of the principal part of the Unegt Uul ridge and in the lock of the Khoid Ulaan Sair Valley. Amphibolites are commonly dark to black-green, fine-grained rocks, which alternate with greenish-grey amphibole-biotitic gneisses. The amphibolites exhibit lepidonematoblastic and nematogranoblastic texture and schistose or banded structure. They are composed of plagioclase, hornblende, quartz, biotite $\pm \mathrm{K}$-feldspar \pm garnet. These minerals are often replaced by sericite, chlorite, epidote and iron oxides in altered domains. Apatite, titanite and opaque minerals are accessoric.

Plagioclase from amphibolites shows wide compositional variation from andesine to bytownite $\left(\mathrm{An}_{34-81}\right)$; plagioclases included in amphibole have an exclusively bytownite composition $\left(\mathrm{An}_{71}\right)$. On the other end of this spectrum, albites $\left(\mathrm{An}_{8}\right)$ are also present in some cases. Garnets from amphibolites (Fig. 4a-b) $\left(\mathrm{Alm}_{55-65} \mathrm{Grs}_{24}\right.$ ${ }_{36} \mathrm{Sps}_{1-8} \operatorname{Prp}_{3-12} \mathrm{Adr}_{1-3}$ ) show zoning with slightly increasing or nearly constant Prp component contents and decreasing Sps contents from core to rim. Biotites (Fig. 4c) have $\mathrm{X}_{\mathrm{Fe}}=0.73-0.76$ and $\mathrm{Al}^{\mathrm{IV}}=2.48-2.75$. Amphiboles cor- respond mostly to ferrotschermakite (Leake et al. 1997) with $\mathrm{X}_{\mathrm{Mg}}=0.25-0.29$ (Fig. $4 \mathrm{~d}$ ). The lenses of medium- to coarse-grained gabbro are confined to amphibolite bodies. These gabbroic rocks are composed of andesine to labradorite, hornblende, biotite, opaque minerals, titanite, epidote and accessoric zircon.

Lenses of metagabbros and serpentinites form a part of tectonic mélange and their relationships to metamorphic rocks and granites remain unclear.

Mica schists are lepidoblastic, medium-grained, crenulated rocks. The mineral assemblage of the studied sample includes quartz, plagioclase, muscovite \pm biotite \pm garnet. Modal composition of gneisses is rather similar, and the two rock types differ mainly in textural characteristics and presence of $\mathrm{K}$-feldspar in the gneisses. The gneisses consist of quartz, orthoclase, plagioclase, biotite, muscovite and garnet. Petrographic types with amphibole are also present. The common accessories are represented by zircon, apatite and opaque minerals. Garnets from the mica schist and gneisses are chemically relatively homogenous, in both of the rock types Alm component predominates $\left(\mathrm{Alm}_{64-79} \mathrm{Grs}_{1-9} \mathrm{Sps}_{3-29} \operatorname{Prp}_{4-12}\right)$ (Fig. $\left.4 \mathrm{a}-\mathrm{b}\right)$. In contrast to garnets from amphibolites of the UUC, garnets from mica schists show weak rimward increase in Sps and slight decrease in Prp components (Fig. 5). Plagioclase from mica schist is oligoclase $\left(\mathrm{An}_{15-29}\right)$. Biotites are enriched in $\mathrm{Mg}\left(\mathrm{X}_{\mathrm{Fe}}=0.30-0.32\right)$ and slightly in $\mathrm{Al}^{\mathrm{IV}}$ (2.60-2.69) compared to biotites from the amphibolite.

The migmatized gneisses are relatively rare; they show usually banded structure comprising light brown biotiterich streaks alternating with light grey bands dominated by the quartz-feldspathic groundmass of quartz-plagioclase-K-feldspar composition. In addition, the quartzofeldspathic bands contain garnet and sillimanite.

\subsection{Chandman Khayrkhan Crystalline Complex}

The CHC is built by orthogneiss, gneiss, migmatite and amphibolite with calc-silicate lenses. Orthogneisses forming bodies in migmatites mainly on the SE slopes of the Chandman Khayrkhan Uul and north of Khutag Nuur are deformed apophyses of the Variscan Chandman Massif (Economos et al. in print). They are medium-grained rocks, having granodioritic to granitic composition, with granoblastic, locally porphyroblastic texture. The fine-grained varieties form boudined dykes and small lenticular bodies in migmatites and granites on the SE slopes of the Chandman Khayrkhan Uul. The rocks have granular texture that gives a massive impression. Locally they are garnet bearing and, in some cases, the K-feldspar crystals can reach $1 \mathrm{~mm}$ in size.

The transition from orthogneisses to metagranites is marked by the occurrence of red porphyritic metagranite, 


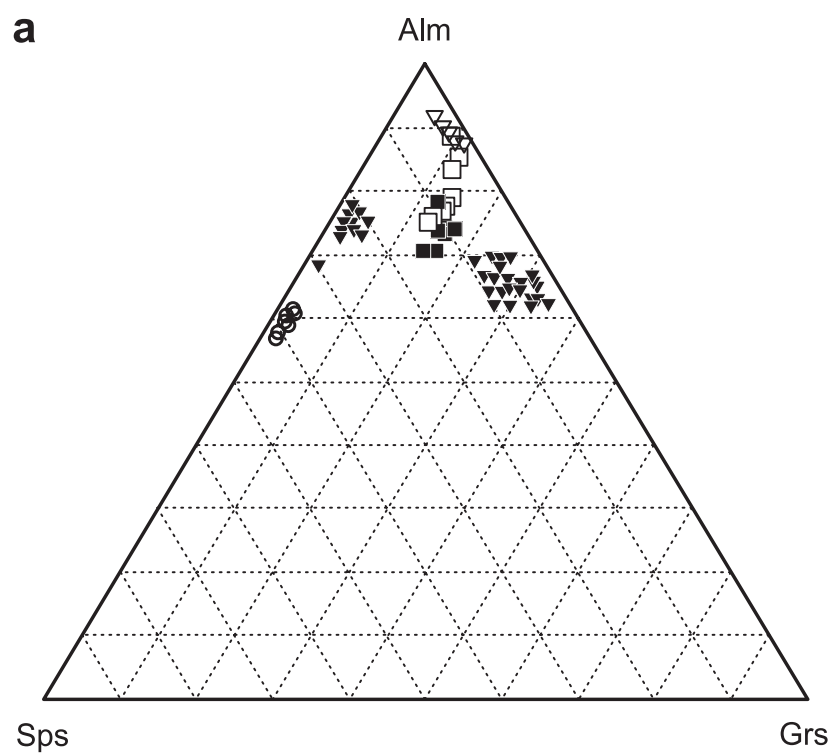

Amphibolites, amphibolitic gneisses

- Khan Khayrkhan C. C.

$\checkmark$ Unegt Uul C. C.

- Chandman Khayrkhan C. C.

C

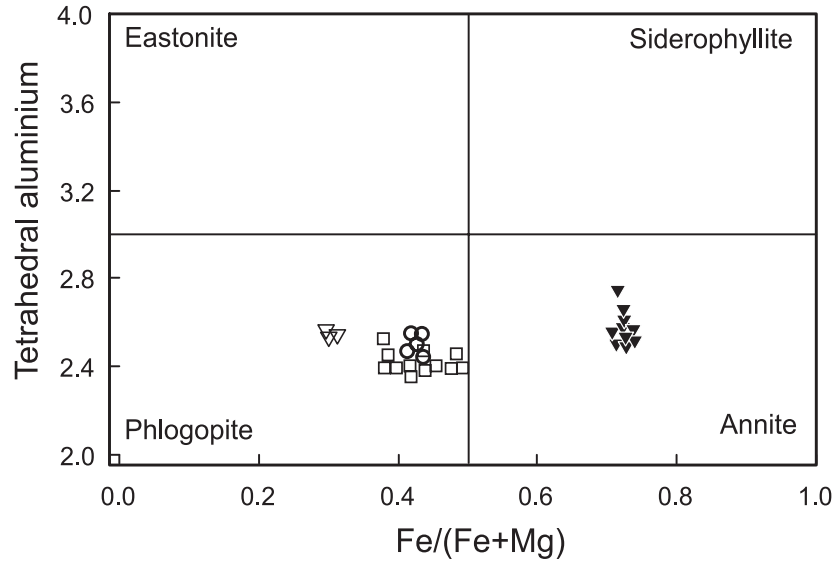

b

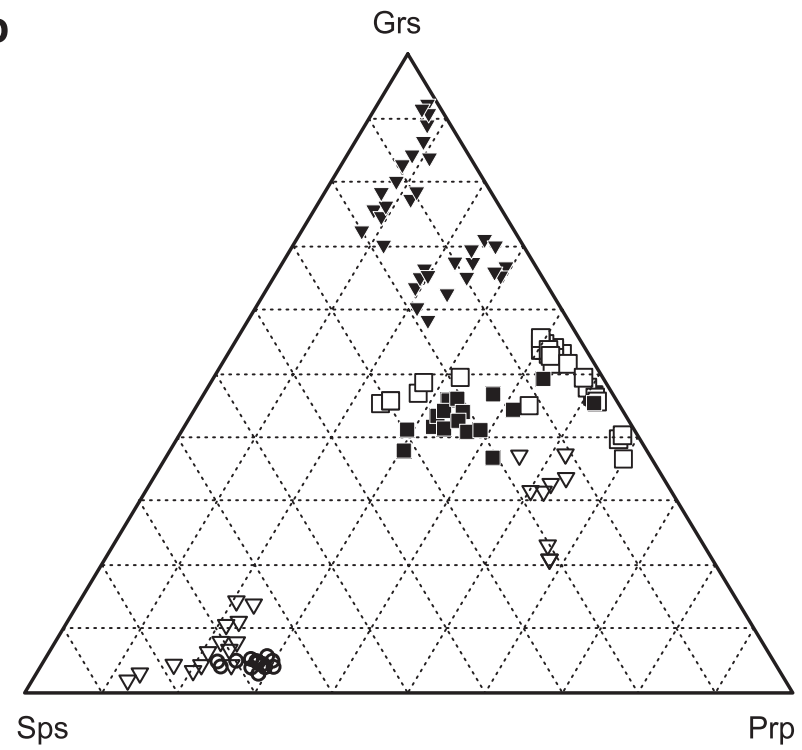

Other rock types

口 metapelites of Khan Khayrkhan C. C.

$\nabla$ metapelites of Unegt Uul C. C

- orthogneisses of Chandman Khayrkhan C. C.

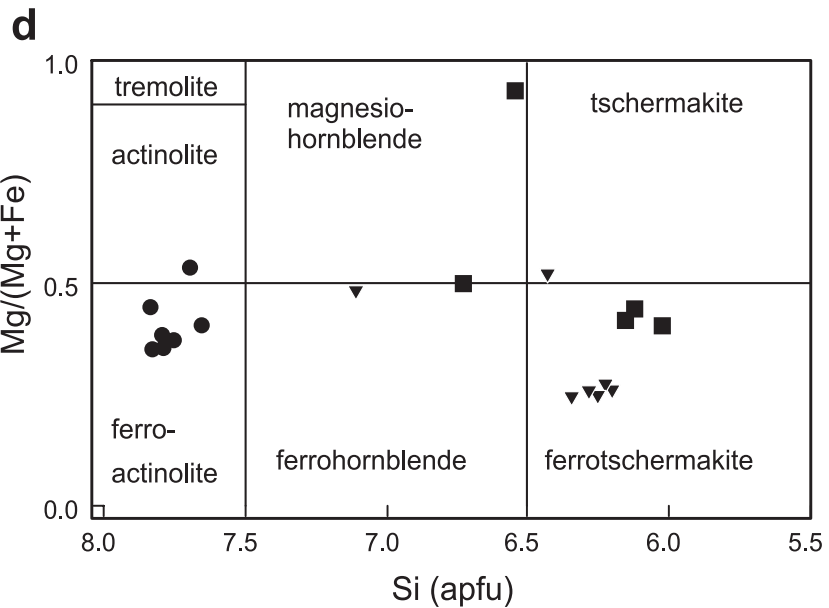

Fig. 4 Classification of rock forming minerals: a, b-garnet (mol. \%), c-biotite (modified according to Guidotti 1984), d - amphibole (Leake et al. 1997). Plotted are chemical compositions of all analyzed minerals in the given rock type within individual crystalline complexes.

metagranodiorite to metadiorite, which are all present as bodies or boudins with ill-defined contacts against surrounding metagranodiorite and metadiorite. Red porphyritic metagranites are fine- to medium-grained rocks with plagioclase and biotite phenocrysts. The groundmass is equigranular and consists of plagioclase (30-40 vol. \%), K-feldspar (20-30\%), quartz (15-20\%) and biotite
(10-15 \%). Plagioclase is subhedral and only locally displays growth zoning. Subhedral to anhedral K-feldspar and quartz are partly recrystallized. Accessory minerals include white mica, epidote, apatite and zircon. Biotite has been locally partially altered to chlorite and secondary epidote.

The metagranitoids are surrounded by biotite migmatite and pearl gneiss with anatectic textures, whereas the 

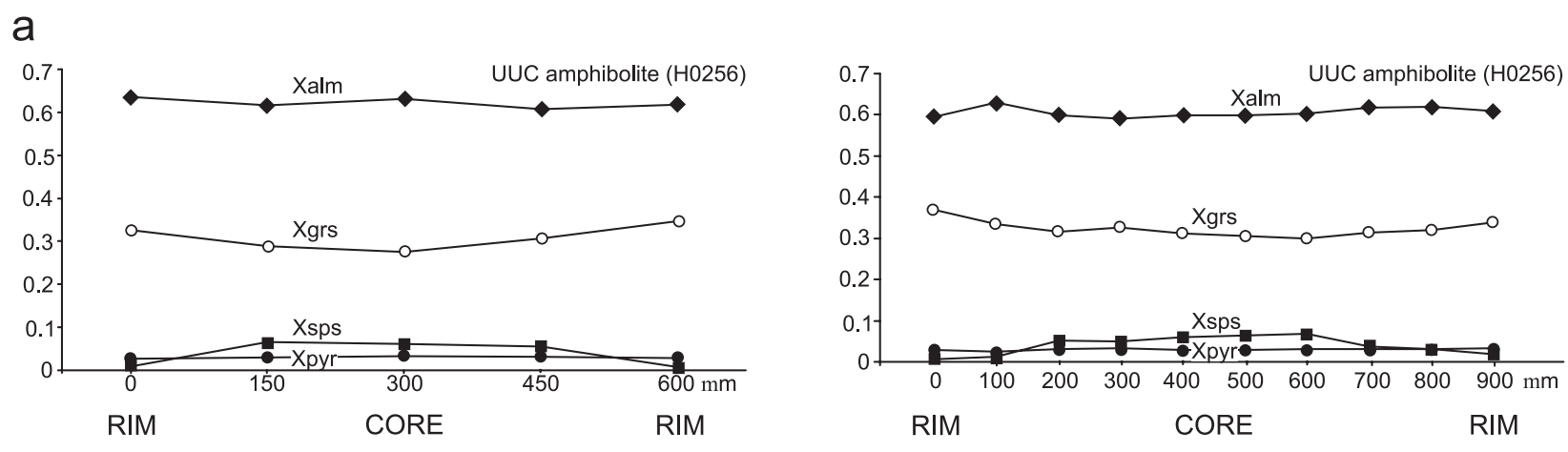

b
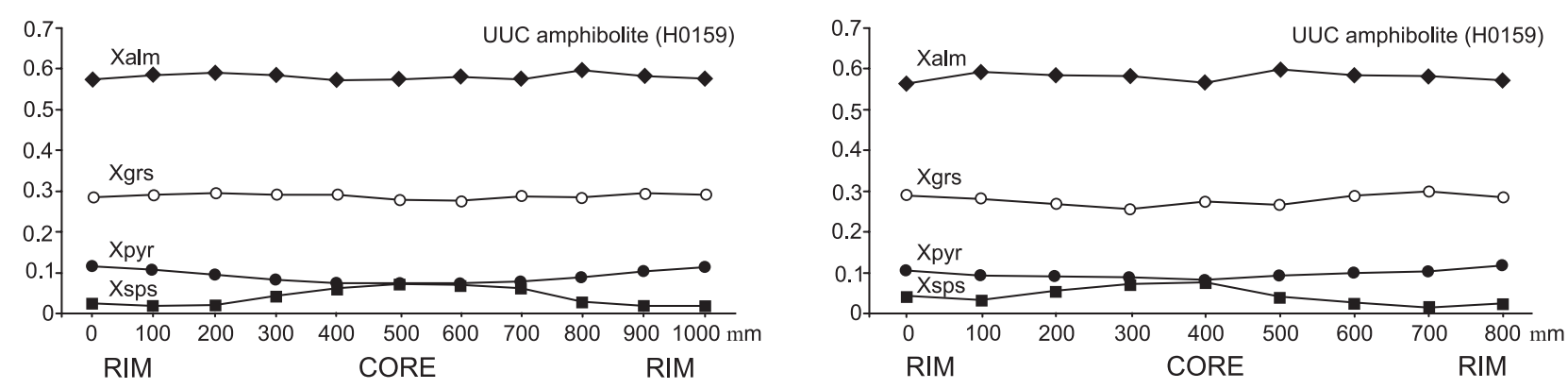

\section{C}
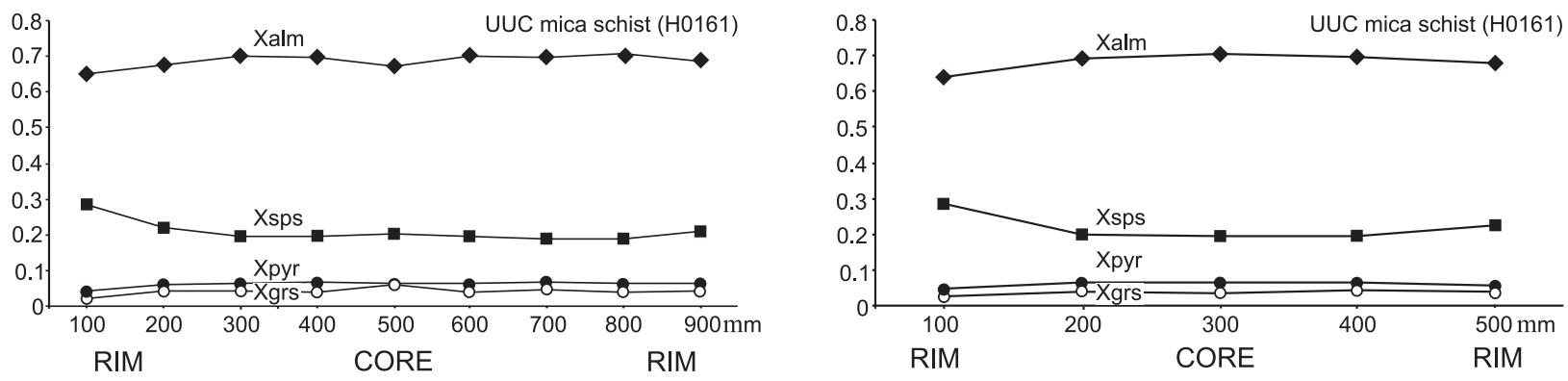

Fig. 5 Garnet profiles from the Unegt Uul Crystalline Complex amphibolite (a-b) and mica schist (c) samples.

migmatites represent the thermal aureole of the intrusion. Pearl gneisses occurring particularly in the $\mathrm{N}$ correspond to the deformed migmatites. The rocks are generally medium- to coarse-grained. Plagioclases are often present as porphyroblasts. The metasediments contain layers of locally migmatitized amphibolites up to several dm thick and consisting mainly of hornblende and plagioclase with minor quartz, biotite, epidote and titanite.

The feldspar-bearing pearl gneiss is typically strongly migmatitic and passes through the nebulitic and schlieren structure to truly anatectic rocks. Pearl gneisses consist of common biotite, plagioclase and quartz. Sometimes there are present muscovite, sillimanite and garnet (Fig. 4a-b). The garnet $\left(\mathrm{Alm}_{51-54} \mathrm{Sps}_{30-36} \operatorname{Prp}_{11-14} \mathrm{Grs}_{0-3} \mathrm{Adr}_{0-3}\right)$ shows a simple retrograde zoning characterised by concomitantly decreasing Prp and increasing Sps contents from core to rim. The Grs component shows a homogenous distribution throughout the garnet grains. Tourmaline is present as subhedral crystals (up to $1 \mathrm{~cm}$ across) at the boundary between melanosome and leucosome. Tourmalines are relatively homogeneous, sometimes with irregular zoning (Mg-rich cores). Biotite corresponds to phlogopite according to the Guidotti's classification (1984) $\left(\mathrm{X}_{\mathrm{Fe}}=\right.$ $0.40-0.42, \mathrm{Al}^{\mathrm{IV}}=2.46-2.58 \mathrm{apfu}-$ Fig. $\left.4 \mathrm{c}\right)$. As accessoric minerals are present apatite and hematite. Migmatites also contain layers of calc-silicate rock up to $30 \mathrm{~cm}$ thick. On the eastern slope of the Chandman Khayrkhan Uul, there are exposed the largest bodies of biotite-amphibole gneiss to amphibolite with metagabbro and calc-silicate lenses. They form enclaves or layers (from several $\mathrm{cm}$ to $1 \mathrm{~km}$ long) surrounded by migmatites or metaigneous rocks. The calc-silicate rocks, amphibolites and mafic gneisses 
show evidence of primary volcano-sedimentary origin. Medium- to fine-grained, commonly banded, granoblastic, nematoblastic or poikiloblastic rocks have varied contents of amphibole (30 to $70 \mathrm{vol}$. \%). A retrograde metamorphic event is indicated by the amphibole composition. Minor biotite, ore minerals and titanite are locally present.

The metagabbro exposed in lenses is dark-grey to black, non-foliated, and very coarse-grained rock.

Calc-silicate rocks are a rare type forming small lenses (up to 10 metres) in amphibolites. They consist mainly of garnet and pyroxene accompanied by interstitial quartz and plagioclase. Amphibole and epidote are present in a calc-silicate layer embedded in the amphibolite. Their mineral composition documents retrogression. Amphiboles are replaced by younger actinolite and ferroactinolite (Fig. 4d) or overgrown by epidote $\left(\mathrm{Ps}_{23-29}\right)$, which sometimes forms independent, isometric grains. Calc-silicates also contain calcic plagioclase $\left(\mathrm{An}_{89-93}\right)$, quartz and secondary chlorite.

In the northernmost part of the unit along the Bogd fault occurs a belt of porphyritic biotite gneisses. They are dark grey rocks composed of plagioclase, biotite, quartz and sometimes K-feldspar or muscovite. Characteristic are deformed porphyroblasts of light feldspar up to $5 \mathrm{~mm}$ in size. The quartz-plagioclase ribbons, which rarely occur along foliation planes, indicate a local anatexis.

\subsection{Khan Khayrkhan Crystalline Complex}

The main rock types of the KKC are various ortho- and paragneisses. Most widespread are fine-grained orthogneisses exposed on the southern slope of the Khangiin Khar Uul and northern slope of the Khan Khayrkhan Uul. Gneisses alternate with amphibolite layers and common marble intercalations enclosing calc-silicate lenses. Some of the gneisses contain amphibole and pass into amphibole gneisses, usually associated with exposures of amphibolite. They are locally strongly deformed, become cataclastic to mylonitized with mortar structures.

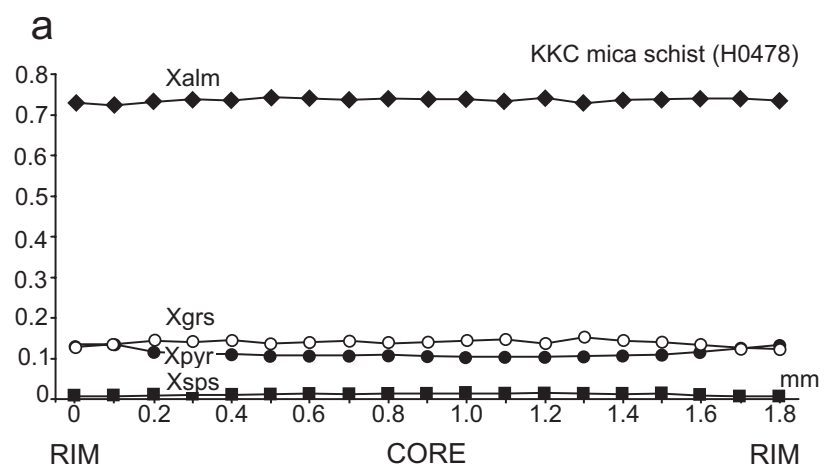

Two-mica orthogneisses crop out on the southern slope of the Khan Khayrkhan mountain range. These orthogneisses are medium-grained, pink-grey rocks with augen structure. They consist of quartz, orthoclase, microcline, plagioclase of albite-oligoclase composition together with muscovite and biotite. Locally occur also garnet-sillimanite varieties. A layer of orthogneiss with 1-3 cm large nests containing muscovite pseudomorphs after sillimanite was also found.

The metabasic rocks include a number of different members - amphibole gneisses, amphibolite, metabasalts and metadiorites to metagabbros. The amphibole gneisses are banded, fine- to very fine-grained rocks of lepidogranoblastic textures, often with garnet porphyroblasts reaching a maximum size of several centimetres. The amphibolites are fine-grained rocks with lepidogranoblastic textures. They contain garnet porphyroblasts up to several $\mathrm{cm}$ across. Fine-grained matrix is composed of quartz, plagioclase, amphibole and biotite. Ilmenite, haematite and titanite are common accessories; zircon is scarce. The main ferromagnesian minerals are partly replaced by actinolite, chlorite, epidote and iron oxides. Amphibole has mostly ferrotschermakite composition (Leake et al. 1997) with $\mathrm{X}_{\mathrm{Mg}}=0.41-0.46$ (Fig. 4d).

Garnet grains from amphibolite (Fig. 4a-b) dominated by almandine component $\left(\mathrm{Alm}_{60-66} \mathrm{Sps}_{7-12} \operatorname{Prp}_{11-14} \mathrm{Grs}_{12-16}\right.$ $\mathrm{Adr}_{1-2}$ ) involve a moderate decrease in Alm component towards the rims. Relatively homogenous distribution of the Prp component shows a slight increase in the marginal parts and negligible increase in one of the internal zones. Nearly inverse pattern is shown by the Grs distribution (Fig. 6a). Plagioclases from amphibolites have andesine to labradorite compositions $\left(\mathrm{An}_{41-58}\right)$.

Garnet-staurolite mica schists crop out in a several tens of meters thick layer NW of the Tsakhir Bulagiin Uul. They exhibit granolepidoblastic to lepidoblastic texture and consist of fine- to very fine-grained matrix composed of a sericite-chlorite-biotite mixture; small grains of quartz, zoisite, and plagioclase are less common. Garnet

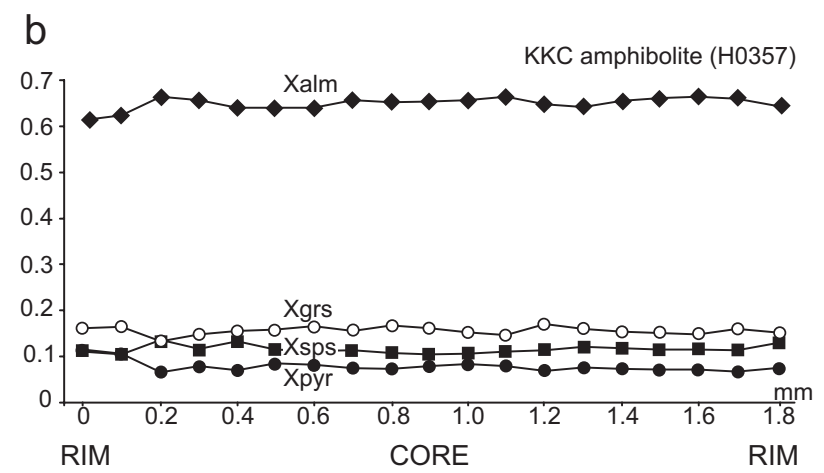

Fig. 6 Garnet profiles from the Khan Khayrkhan Crystalline Complex amphibolite (a) and mica schist (b) samples 
and/or staurolite porphyroblasts, several $\mathrm{cm}$ across, float in the matrix. Kyanite porphyroblasts are also rarely present. Garnet porphyroblasts dominated by the almandine component contain linear trails of small quartz grains, aligned parallel to the foliation and documenting the late to post-deformational garnet growth. Garnet (Alm ${ }_{67-73}$ $\mathrm{Sps}_{0-9} \operatorname{Prp}_{7-14} \mathrm{Grs}_{8-13} \mathrm{Adr}_{2-3}$ ) (Fig. 4a-b) from the mica schist has zoning typical of a single-stage growth (e. g. Tracy 1982), with distinctive rimward increases in $\mathrm{Alm}$ and Prp compensated by antithetic deceases in Grs and Sps components (Fig. 6b). Biotite has nearly the same composition in both the studied rock types (mica schist and amphibolite): $\mathrm{X}_{\mathrm{Fe}}=0.39-0.52, \mathrm{Al}^{\mathrm{IV}}=2.49-2.66$ (Fig. 4c) Columnar crystals of staurolite, in some cases up to first $\mathrm{cm}$ in size, are intergrown by a large number of opaque minerals. In places they are strongly affected by retrogression, and often decomposed to biotite or mixture of quartz, biotite and iron oxides. They are also compositionally uniform $\left(\mathrm{X}_{\mathrm{Fe}}=0.86-0.89\right)$.

Plagioclase from mica schists has oligoclase composition $\left(\mathrm{An}_{26-29}\right)$ in one of the studied samples, and much more basic (andesine to bytownite, $\mathrm{An}_{34-81}$ ) in the second one. The latter was sampled in close spatial relation with an amphibolite layer and such a high basicity of plagioclase likely reflects a preservation of primary composition of plagioclase from a tuffitic source. In some cases the plagioclases may show slight reverse zoning, whereby the core is more sodic than the marginal parts, and corresponds to the andesine $\left(\mathrm{An}_{37}\right)$.

\section{Whole-rock geochemistry}

The newly obtained whole-rock geochemical data from orthogneisses (metagranites) and amphibolites of the KKC and UUC are presented in Tables 1 and 2. They are complemented by $\mathrm{Sr}-\mathrm{Nd}$ isotopic data from one $\mathrm{KHC}$ amphibolite and Nd data from an UUC gabbro. No samples of Chandman Khayrkhan Crystalline Complex were analysed in course of the present study. The data presented in the diagrams (Figs 7-8) are for comparison only and come from Chandman Massif (Economos et al. in print).

Metagranites of the Unegt Uul Crystalline Complex (Fig. 7a) usually show high to very high Ba contents (47-1002 ppm) and variable $\mathrm{Rb} / \mathrm{Sr}$ ratios $(0.1-6.1)$. The $\mathrm{SiO}_{2}$ abundances range between 70 and 75 wt. \%, $\mathrm{A} / \mathrm{CNK}=1.06-1.23$ (Fig. $7 \mathrm{~b}$ ), potassium abundance is high $\left(\mathrm{K}_{2} \mathrm{O}=3.8-4.8\right.$ wt. \%; Fig. 7c) and the total REE contents are very variable (62-329 ppm). Chondrite-normalised (Boynton 1984) REE patterns show slight LREE enrichment $\left(\mathrm{La}_{\mathrm{N}} / \mathrm{Sm}_{\mathrm{N}}=2.7-4.3\right)$, flat HREE $\left(\mathrm{Gd}_{\mathrm{N}} / \mathrm{Yb}_{\mathrm{N}}=\right.$ 1.1-1.2) and moderate to deep negative Eu anomalies $\left(\mathrm{Eu} / \mathrm{Eu}^{*}=0.33-0.61\right)($ Fig. 7e). They fit the field of syn- collisional, within plate and volcanic arc associations in the $\mathrm{Rb}$ vs. Ta $+\mathrm{Yb}$ diagram of Pearce (1984) (Fig. 7d).

Amphibolites of the Unegt Uul Crystalline Complex are tholeiitic with $\mathrm{SiO}_{2}=48.6-51.1$ wt. $\%$ and $\mathrm{K}_{2} \mathrm{O} / \mathrm{Na}_{2} \mathrm{O}$ $=0.1-1.0$. Amphibolites correspond to MORB in geotectonic discrimination diagram of Meschede (1986) (Fig. 8b). Compared to N-MORB (Sun and McDonough 1989), the amphibolites are somewhat enriched in lithophile elements (Fig. 8a). Still, the REE contents are very low (34-43 ppm) and chondrite-normalized REE patterns flat as demonstrated by low LREE/HREE and LREE/MREE ratios $\left(\mathrm{La}_{\mathrm{N}} / \mathrm{Yb}_{\mathrm{N}}=1.4, \mathrm{La}_{\mathrm{N}} / \mathrm{Sm}_{\mathrm{N}}=1.0-1.2\right.$; Fig. 8c).

Exact age of the gabbro sample (D0873), which comes from a tectonic mélange, is not at all clear. Fortunately the age-corrected $\mathrm{Nd}$ isotopic composition does not vary greatly with time and thus it in any case demonstrates a large proportion of the crustal material $\left(\varepsilon_{\mathrm{Nd}}^{900}=-4.0\right)$, precluding direct derivation from the Earth's mantle.

Granitic orthogneisses of the Khan Khayrkhan Crystalline Complex are medium-K calc-alkaline, slightly metaluminous to peraluminous rocks $(\mathrm{A} / \mathrm{CNK}=0.9-1.3$; $\left.\mathrm{K}_{2} \mathrm{O} / \mathrm{Na}_{2} \mathrm{O}=0.4-1.2\right)$. Trace-element signatures of the metagranitic rocks indicate a volcanic-arc character sensu Pearce et al (1984). Chondrite-normalised patterns show well fractionated LREE and flat trend for the $\operatorname{HREE}\left(\mathrm{La}_{\mathrm{N}} / \mathrm{Yb}_{\mathrm{N}}=6.5-11.5, \mathrm{La}_{\mathrm{N}} / \mathrm{Sm}_{\mathrm{N}}=3.89-6.43\right)$. The $\mathrm{Eu}$ anomaly is variably negative to negligible $\left(\mathrm{Eu} / \mathrm{Eu}^{*}=\right.$ 0.5-1.0). (Fig. 7a-d, f)

Amphibolites from the Khan Khayrkhan Crystalline Complex are tholeiitic to calc-alkaline with $\mathrm{SiO}_{2}=43.1-$ 47.8 wt. $\%$ and very variable $\mathrm{K}_{2} \mathrm{O} / \mathrm{Na}_{2} \mathrm{O}$ ratios $\left(\mathrm{K}_{2} \mathrm{O} / \mathrm{Na}_{2} \mathrm{O}\right.$ $=0.05-1.80)$. Chondrite-normalized REE patterns show a fair fractionation as demonstrated by LREE/HREE and LREE/MREE ratios $\left(\mathrm{La}_{\mathrm{N}} / \mathrm{Yb}_{\mathrm{N}}=3.0-6.4, \mathrm{La}_{\mathrm{N}} / \mathrm{Sm}_{\mathrm{N}}\right.$ $=1.6-2.7)$. They are strongly enriched in lithophile and weakly in HFS elements compared with N-MORB (Sun and McDonough 1989) (Fig. 8b). Amphibolite samples fit into fields of within-plate basalt in the discrimination diagram of Meschede (1986) (Fig. 8a).

The trace-element composition of the amphibolite H0477 resembles EMORB (Fig. 8a-b). Accordingly, the $\mathrm{Sr}-\mathrm{Nd}$ isotopic signature is primitive, in line with its likely derivation from a moderately depleted mantle source in Cambrian times $\left(\varepsilon_{\mathrm{Nd}}^{550}=+8.4,{ }^{87} \mathrm{Sr} /{ }^{86} \mathrm{Sr}_{550}=\right.$ $\left.0.7040, \mathrm{~T}_{\mathrm{Nd}}^{\mathrm{DM}}=0.56 \mathrm{Ga}\right)$.

\section{Metamorphic conditions}

\subsection{Unegt Uul Crystalline Complex}

Three samples from the UUC have been studied to estimate metamorphic conditions of the unit: a mica schist 

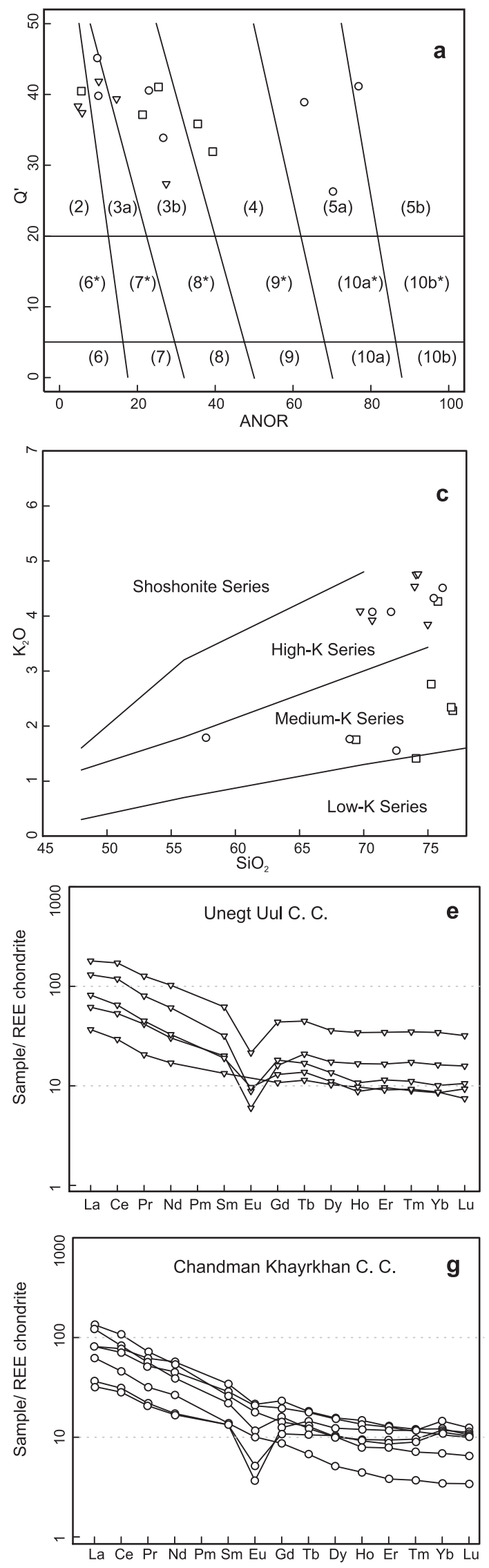
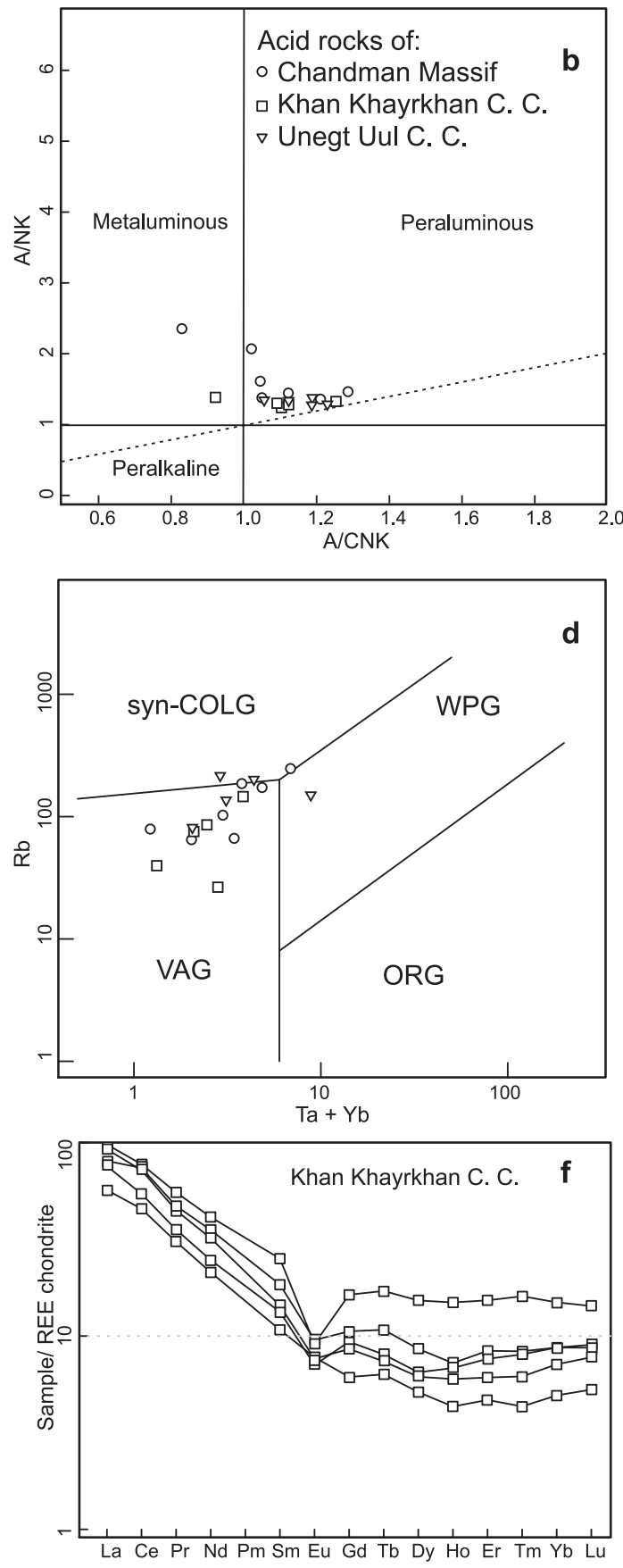

Fig. 7 Geochemical characteristics of acid rocks - granites and orthogneisses of UUC, KKC and CHC: a - Q'-ANOR diagram of Streckeisen and Le Maitre (1979) based on the Improved Granite Mesonorm (Mielke and Winkler 1979): 2 - alkali feldspar granite, 3 - granite, 4 - granodiorite, 5 - tonalite, $6^{*}$ - quartz-alkali feldspar syenite, $7 *$ quartz syenite, $8^{*}$ - quartz monzonite, $9^{*}$ - quartz monzonite/quartz monzogabbro, $10^{*}$ - quartz diorite/quartz gabbro, 6 - alkali feldspar syenite, 7 - syenite, 8 - monzonite, 9 - monzodiorite/monzogabbro 10 - diorite/gabbro; b - Shand's index (A/CNK - A/NK) plot (Shand 1943; Maniar and Piccoli 1989); c - diagram $\mathrm{SiO}_{2}-\mathrm{K}_{2} \mathrm{O}$ of Peccerillo and Taylor (1976); d - geotectonic discrimination plot for metagranitic rocks (Pearce et al. 1984); e-g chondrite-normalized (Boynton 1984) REE patterns for individual crystalline complexes (C. C.). 
Tab. 1 Whole-rock analyses (major elements in wt. \%, trace elements in ppm) for acid rocks from the eastern Mongolian Altay.

\begin{tabular}{|c|c|c|c|c|c|c|c|c|c|}
\hline Sample & H0168 & H0267A & H0332 & H0333 & H0335 & R0221 & Z0992 & AB6-8 & D0816 \\
\hline Sheet_no & L-47-101A & L-47-101B & L-47-101A & L-47-101A & L-47-101A & L-47-101A & L-47-101A & L-47-100 & L-47-101V \\
\hline E_coord. $\left({ }^{\circ}\right)$ & 98.22329 & 98.37318 & 98.16809 & 98.19587 & 98.21791 & 98.08679 & 98.17676 & 97.96672 & 45.21626 \\
\hline N_coord. $\left(^{\circ}\right)$ & 45.27573 & 45.23777 & 45.26511 & 45.26924 & 45.28201 & 45.29015 & 45.27202 & 98.15597 & 45.15311 \\
\hline Rock & orthogneiss & orthogneiss & orthogneiss & orthogneiss & orthogneiss & orthogneiss & orthogneiss & orthogneiss & orthogneiss \\
\hline Formation & $\mathrm{CHC}$ & $\mathrm{CHC}$ & $\mathrm{CHC}$ & $\mathrm{CHC}$ & $\mathrm{CHC}$ & $\mathrm{CHC}$ & $\mathrm{CHC}$ & KKC & $\mathrm{KKC}$ \\
\hline $\mathrm{SiO}_{2}$ & 75.48 & 72.56 & 57.72 & 76.12 & 72.12 & 68.89 & 70.64 & 69.30 & 74.08 \\
\hline $\mathrm{Al}_{2} \mathrm{O}_{3}$ & 14.00 & 14.23 & 15.43 & 13.43 & 13.19 & 14.63 & 14.16 & 13.45 & 13.86 \\
\hline $\mathrm{Fe}_{2} \mathrm{O}_{3}$ & 1.05 & 2.49 & 8.39 & 1.15 & 2.00 & 4.62 & 2.92 & 2.56 & 2.01 \\
\hline MgO & 0.13 & 0.71 & 4.14 & 0.19 & 0.34 & 1.86 & 0.69 & 1.05 & 0.62 \\
\hline $\mathrm{CaO}$ & 0.66 & 2.63 & 6.63 & 0.68 & 1.47 & 3.99 & 1.78 & 2.67 & 0.82 \\
\hline $\mathrm{Na}_{2} \mathrm{O}$ & 3.45 & 4.35 & 2.82 & 2.63 & 2.85 & 3.14 & 3.56 & 4.76 & 5.81 \\
\hline $\mathrm{K}_{2} \mathrm{O}$ & 4.32 & 1.55 & 1.78 & 4.51 & 4.07 & 1.76 & 4.07 & 1.75 & 1.41 \\
\hline $\mathrm{TiO}_{2}$ & 0.05 & 0.27 & 1.20 & 0.08 & 0.18 & 0.46 & 0.43 & 0.24 & 0.27 \\
\hline $\mathrm{P}_{2} \mathrm{O}_{5}$ & 0.08 & 0.10 & 0.46 & 0.08 & 0.05 & 0.14 & 0.13 & 0.06 & 0.06 \\
\hline MnO & 0.10 & 0.05 & 0.13 & 0.04 & 0.03 & 0.07 & 0.03 & 0.06 & 0.06 \\
\hline LOI & 0.60 & 0.60 & 0.80 & 0.90 & 1.00 & 0.40 & 1.40 & 3.90 & 1.00 \\
\hline TOT_C & 0.01 & 0.01 & 0.01 & 0.01 & 0.06 & 0.01 & 0.10 & 0.83 & 0.04 \\
\hline Total & 99.92 & 99.54 & 99.52 & 99.81 & 97.30 & 99.97 & 99.82 & 99.81 & 100.00 \\
\hline Sc & 4 & 3 & 18 & 4 & 3 & 11 & 4 & 4 & 3 \\
\hline $\mathbf{B a}$ & 119.2 & 296.6 & 404.4 & 174.3 & 733.9 & 249.9 & 1305.0 & 559.7 & 276.4 \\
\hline $\mathrm{Be}$ & 4 & 2 & 2 & 3 & 1 & 3 & 2 & 1 & 2 \\
\hline Co & 0.8 & 3.9 & 27.6 & 1.0 & 2.6 & 12.2 & 5.5 & 4.0 & 2.9 \\
\hline Cs & 8.6 & 3.9 & 1.9 & 4.4 & 9.1 & 9.3 & 1.7 & 1.3 & 0.3 \\
\hline Ga & 21.4 & 20.0 & 20.8 & 17.8 & 17.0 & 21.4 & 15.7 & 12.8 & 13.9 \\
\hline Hf & 2.4 & 4.3 & 5.4 & 1.9 & 4.4 & 6.2 & 6.8 & 3.3 & 5.5 \\
\hline Nb & 32.0 & 7.0 & 14.9 & 19.1 & 11.0 & 11.5 & 9.0 & 4.6 & 10.7 \\
\hline $\mathbf{R b}$ & 244.9 & 78.8 & 66.9 & 173.3 & 185.3 & 102.8 & 65.1 & 39.9 & 26.8 \\
\hline Sn & 2 & 2 & 3 & 2 & 2 & 3 & 1 & 1 & 2 \\
\hline $\mathrm{Sr}$ & 28.6 & 312.8 & 382.1 & 50.3 & 159.8 & 183.2 & 278.0 & 156.1 & 161.2 \\
\hline Ta & 3.8 & 0.5 & 0.9 & 2.5 & 1.3 & 0.8 & 0.6 & 0.3 & 1.0 \\
\hline Th & 6.7 & 10.0 & 4.4 & 7.2 & 32.1 & 8.1 & 6.5 & 8.2 & 9.8 \\
\hline $\mathbf{U}$ & 1.3 & 1.4 & 1.2 & 1.6 & 2.5 & 1.0 & 1.3 & 1.8 & 1.5 \\
\hline $\mathbf{V}$ & - & 26 & 173 & 6 & 14 & 71 & 29 & 28 & 16 \\
\hline W & 0.5 & 0.2 & 0.1 & 2.4 & 0.7 & 0.2 & 0.2 & 0.4 & 0.7 \\
\hline $\mathbf{Z r}$ & 48.6 & 148.7 & 226.7 & 45.5 & 147.0 & 194.4 & 267.9 & 98.1 & 166.2 \\
\hline $\mathbf{Y}$ & 25.8 & 9.7 & 29.0 & 21.9 & 21.1 & 25.2 & 17.9 & 10.4 & 17.9 \\
\hline Мo & 0.2 & 0.2 & 0.3 & 0.2 & 0.2 & 0.2 & 0.2 & 0.4 & 0.3 \\
\hline $\mathrm{Cu}$ & 6.3 & 7.9 & 53.0 & 6.9 & 7.6 & 20.2 & 6.1 & 15.2 & 10.8 \\
\hline $\mathbf{P b}$ & 1.7 & 2.7 & 1.1 & 2.8 & 6.0 & 1.6 & 3.2 & 6.6 & 1.8 \\
\hline Zn & 9 & 48 & 61 & 13 & 25 & 74 & 35 & 39 & 31 \\
\hline $\mathbf{N i}$ & 2.2 & 5.1 & 49.9 & 2.1 & 3.0 & 32.8 & 4.4 & 6.6 & 3.6 \\
\hline As & 0.5 & 0.5 & 0.8 & 0.6 & 0.6 & - & 0.5 & 3.1 & 0.8 \\
\hline Cd & 0.1 & - & - & - & 0.1 & 0.1 & - & - & - \\
\hline Sb & - & - & - & - & 0.1 & - & - & - & 0.1 \\
\hline $\mathbf{B i}$ & 0.1 & - & - & 0.2 & 0.1 & 0.1 & - & 0.1 & 0.1 \\
\hline $\mathbf{A u}$ & 1.4 & 1.0 & 1.1 & 0.9 & - & 17.1 & 4.3 & - & 0.8 \\
\hline Tl & 0.1 & 0.3 & 0.3 & 0.1 & 0.3 & 0.5 & 0.1 & - & - \\
\hline La & 10.0 & 19.4 & 25.2 & 11.3 & 37.8 & 25.2 & 41.7 & 17.6 & 24.9 \\
\hline $\mathrm{Ce}$ & 22.9 & 37.2 & 62.5 & 25.1 & 67.0 & 57.3 & 86.7 & 36.7 & 59.8 \\
\hline $\operatorname{Pr}$ & 2.52 & 3.88 & 7.55 & 2.68 & 6.87 & 6.32 & 8.83 & 3.75 & 5.73 \\
\hline Nd & 10.1 & 15.9 & 34.3 & 10.4 & 23.6 & 27.2 & 32.5 & 12.8 & 21.2 \\
\hline Sm & 2.6 & 2.7 & 6.7 & 2.6 & 4.3 & 5.6 & 5.1 & 2.1 & 3.6 \\
\hline Eu & 0.27 & 0.74 & 1.57 & 0.38 & 0.86 & 1.52 & 1.32 & 0.57 & 0.70 \\
\hline Gd & 3.23 & 2.25 & 6.02 & 2.80 & 4.14 & 5.08 & 3.69 & 1.59 & 2.74 \\
\hline $\mathbf{T b}$ & 0.69 & 0.32 & 0.86 & 0.50 & 0.58 & 0.84 & 0.61 & 0.30 & 0.51 \\
\hline Dy & 3.97 & 1.65 & 5.03 & 3.35 & 3.23 & 4.92 & 3.26 & 1.65 & 2.76 \\
\hline Но & 0.86 & 0.32 & 1.06 & 0.66 & 0.68 & 0.97 & 0.57 & 0.31 & 0.52 \\
\hline Er & 2.46 & 0.80 & 2.70 & 1.80 & 1.97 & 2.65 & 1.64 & 0.98 & 1.76 \\
\hline $\mathbf{T m}$ & 0.38 & 0.12 & 0.39 & 0.29 & 0.31 & 0.37 & 0.23 & 0.14 & 0.27 \\
\hline $\mathbf{Y b}$ & 3.04 & 0.72 & 2.54 & 2.35 & 2.46 & 2.21 & 1.44 & 1.03 & 1.82 \\
\hline Lu & 0.40 & 0.11 & 0.34 & 0.33 & 0.36 & 0.32 & 0.21 & 0.17 & 0.29 \\
\hline$\sum$ REE & 63.42 & 86.11 & 156.76 & 64.54 & 154.16 & 140.50 & 187.80 & 79.69 & 126.60 \\
\hline
\end{tabular}


Tab. 1 continued Whole-rock analyses (major elements in wt. \%, trace elements in ppm) for acid rocks from the eastern Mongolian Altay.

\begin{tabular}{|c|c|c|c|c|c|c|c|c|c|}
\hline Sample & H0352 & R0196 & R0237 & A1000-2 & D0713 & D0714 & H0165 & H0272 & H1291 \\
\hline Sheet_no & L-47-101A & L-47-101A & L-47-101A & L-47-101B & L-47-101G & L-47-101G & L-47-101A & L-47-101B & L-47-101A \\
\hline E_coord. $\left({ }^{\circ}\right)$ & 98.03787 & 98.00885 & 98.07759 & 98.36456 & 98.41703 & 98.44172 & 98.24330 & 98.27132 & 98.24266 \\
\hline N_coord. $\left(^{\circ}\right)$ & 45.18757 & 45.20836 & 45.17450 & 45.28449 & 45.27529 & 45.27385 & 45.29260 & 45.29054 & 45.29318 \\
\hline Rock & orthogneiss & orthogneiss & orthogneiss & granite & granite & granite & rhyolite & granite & granite \\
\hline Formation & KKC & KKC & KKC & UUC & UUC & UUC & UUC & UUC & UUC \\
\hline $\mathrm{SiO}_{2}$ & 76.78 & 75.24 & 75.76 & 74.07 & 69.72 & 74.05 & 70.13 & 74.99 & 70.66 \\
\hline $\mathrm{Al}_{2} \mathrm{O}_{3}$ & 12.92 & 13.89 & 13.78 & 13.44 & 15.50 & 13.23 & 14.22 & 14.23 & 13.14 \\
\hline $\mathrm{Fe}_{2} \mathrm{O}_{3}$ & 1.27 & 1.63 & 1.23 & 1.89 & 1.73 & 2.07 & 3.31 & 0.98 & 5.82 \\
\hline MgO & 0.27 & 0.22 & 0.11 & 0.52 & 0.62 & 0.48 & 0.78 & 0.08 & 0.47 \\
\hline $\mathrm{CaO}$ & 0.95 & 0.91 & 0.32 & 0.87 & 1.78 & 0.98 & 1.05 & 0.30 & 0.40 \\
\hline $\mathrm{Na}_{2} \mathrm{O}$ & 4.58 & 4.71 & 3.53 & 2.79 & 4.30 & 2.95 & 3.51 & 4.18 & 3.71 \\
\hline $\mathrm{K}_{2} \mathrm{O}$ & 2.34 & 2.77 & 4.27 & 4.75 & 4.08 & 4.76 & 5.14 & 3.84 & 3.92 \\
\hline $\mathrm{TiO}_{2}$ & 0.17 & 0.18 & 0.08 & 0.26 & 0.25 & 0.22 & 0.46 & 0.02 & 0.56 \\
\hline $\mathrm{P}_{2} \mathrm{O}_{5}$ & 0.04 & 0.04 & 0.02 & 0.20 & 0.05 & 0.04 & 0.11 & 0.02 & 0.14 \\
\hline MnO & 0.02 & 0.03 & 0.02 & 0.02 & 0.03 & 0.03 & 0.04 & 0.01 & 0.08 \\
\hline LOI & 0.50 & 0.60 & 1.20 & 1.00 & 1.80 & 1.10 & 1.20 & 1.00 & 1.00 \\
\hline TOT_C & 0.02 & 0.03 & 0.02 & 0.05 & 0.27 & 0.04 & 0.15 & 0.03 & 0.03 \\
\hline Total & 99.84 & 100.22 & 100.32 & 99.81 & 99.86 & 99.91 & 99.95 & 99.65 & 99.90 \\
\hline Sc & 2 & 2 & 2 & 4 & 4 & 3 & 5 & 4 & 10 \\
\hline $\mathbf{B a}$ & 441.0 & 521.0 & 479.0 & 495.6 & 1002.0 & 759.8 & 717.2 & 47.0 & 507.1 \\
\hline $\mathrm{Be}$ & 3 & 1 & 1 & 2 & 2 & 2 & 2 & 3 & 3 \\
\hline Co & 1.8 & 1.6 & 1.0 & 2.2 & 2.4 & 2.9 & 5.8 & 0.8 & 4.0 \\
\hline Cs & 1.1 & 1.7 & 2.1 & 12.3 & 2.1 & 2.4 & 2.7 & 5.7 & 1.9 \\
\hline Ga & 14.7 & 15.7 & 15.1 & 17.9 & 14.9 & 15.4 & 18.4 & 21.2 & 24.7 \\
\hline Hf & 2.9 & 3.1 & 3.1 & 3.7 & 3.9 & 4.7 & 6.0 & 1.5 & 13.4 \\
\hline Nb & 7.2 & 7.9 & 8.9 & 9.4 & 5.1 & 8.6 & 10.1 & 10.3 & 24.0 \\
\hline $\mathbf{R b}$ & 75.8 & 85.1 & 146.5 & 205.8 & 80.7 & 137.1 & 181.5 & 218.3 & 151.6 \\
\hline Sn & 1 & - & 5 & 3 & 2 & 3 & 4 & 4 & 6 \\
\hline $\mathrm{Sr}$ & 86.6 & 110.5 & 86.5 & 126.4 & 593.2 & 241.3 & 118.5 & 36.1 & 81.6 \\
\hline Ta & 0.6 & 0.6 & 0.7 & 1.0 & 0.3 & 1.0 & 1.0 & 1.1 & 1.7 \\
\hline Th & 12.0 & 8.5 & 15.9 & 11.0 & 12.8 & 29.2 & 21.0 & 10.7 & 31.8 \\
\hline $\mathbf{U}$ & 1.4 & 1.3 & 6.7 & 4.1 & 2.4 & 4.1 & 5.3 & 4.4 & 4.0 \\
\hline $\mathbf{V}$ & 11 & 11 & - & 17 & 24 & 26 & 30 & - & 28 \\
\hline W & 5.2 & 0.7 & 0.4 & 2.8 & 0.5 & 0.2 & 1.2 & 1.3 & 0.6 \\
\hline $\mathbf{Z r}$ & 83.3 & 118.2 & 80.8 & 112.0 & 146.8 & 108.2 & 188.0 & 31.4 & 472.0 \\
\hline $\mathbf{Y}$ & 14.1 & 16.2 & 31.0 & 38.2 & 23.0 & 26.0 & 31.2 & 22.3 & 68.9 \\
\hline Мo & 0.4 & 0.7 & 7.0 & 0.2 & 0.3 & 1.0 & 0.3 & 0.2 & 0.8 \\
\hline $\mathrm{Cu}$ & 8.4 & 5.3 & 6.8 & 4.1 & 7.5 & 10.6 & 26.5 & 8.4 & 17.9 \\
\hline $\mathbf{P b}$ & 3.4 & 2.2 & 2.8 & 5.2 & 14.0 & 6.7 & 24.9 & 8.8 & 12.5 \\
\hline Zn & 16 & 17 & 26 & 23 & 25 & 31 & 45 & 12 & 129 \\
\hline $\mathbf{N i}$ & 2.5 & 4.3 & 2.1 & 4.6 & 3.7 & 3.7 & 5.6 & 1.9 & 4.1 \\
\hline As & - & 1.2 & 0.9 & 5.0 & - & - & 0.8 & 2.7 & 0.7 \\
\hline Cd & 0.1 & - & - & - & 0.1 & - & 0.1 & - & 0.1 \\
\hline Sb & - & - & - & 0.2 & - & - & - & - & - \\
\hline $\mathbf{B i}$ & - & - & 0.1 & 0.1 & 0.1 & 0.2 & 0.2 & 0.6 & 0.1 \\
\hline $\mathbf{A u}$ & - & - & - & 1.0 & 0.7 & - & 0.8 & 1.1 & 0.9 \\
\hline Tl & 0.1 & 0.1 & 0.1 & 0.6 & - & - & - & 0.1 & 0.1 \\
\hline La & 28.6 & 23.4 & 30.3 & 19.1 & 25.3 & 40.5 & 43.2 & 11.4 & 55.8 \\
\hline $\mathrm{Ce}$ & 58.2 & 43.9 & 62.4 & 43.1 & 52.4 & 95.9 & 89.7 & 23.7 & 138.8 \\
\hline $\operatorname{Pr}$ & 5.44 & 4.33 & 6.74 & 5.09 & 5.48 & 9.77 & 9.25 & 2.51 & 15.46 \\
\hline Nd & 19.2 & 14.8 & 24.7 & 18.2 & 19.7 & 36.5 & 39.0 & 10.2 & 61.6 \\
\hline Sm & 2.8 & 2.6 & 4.9 & 3.9 & 3.7 & 6.2 & 6.4 & 2.6 & 12.1 \\
\hline Eu & 0.56 & 0.52 & 0.67 & 0.44 & 0.71 & 0.65 & 0.95 & - & 1.58 \\
\hline Gd & 2.22 & 2.42 & 4.23 & 4.15 & 3.37 & 4.70 & 6.02 & 2.79 & 11.35 \\
\hline $\mathbf{T b}$ & 0.35 & 0.38 & 0.81 & 0.99 & 0.65 & 0.80 & 0.87 & 0.54 & 2.12 \\
\hline Dy & 1.98 & 2.09 & 4.91 & 5.59 & 3.56 & 4.37 & 5.04 & 3.31 & 11.57 \\
\hline Но & 0.43 & 0.49 & 1.07 & 1.20 & 0.63 & 0.77 & 1.02 & 0.70 & 2.46 \\
\hline Er & 1.28 & 1.60 & 3.21 & 3.48 & 2.02 & 2.41 & 2.84 & 1.91 & 7.25 \\
\hline $\mathbf{T m}$ & 0.20 & 0.26 & 0.52 & 0.56 & 0.29 & 0.36 & 0.44 & 0.30 & 1.13 \\
\hline $\mathbf{Y b}$ & 1.49 & 1.82 & 3.12 & 3.40 & 1.78 & 2.11 & 2.98 & 1.81 & 7.20 \\
\hline Lu & 0.25 & 0.28 & 0.46 & 0.51 & 0.30 & 0.34 & 0.42 & 0.24 & 1.03 \\
\hline$\sum$ REE & 123.00 & 98.89 & 148.04 & 109.71 & 119.89 & 205.38 & 208.13 & 61.96 & 329.45 \\
\hline
\end{tabular}


Tab. 2 Whole-rock analyses (major elements in wt. \%, trace elements in ppm) for basic rocks from the eastern Mongolian Altay.

\begin{tabular}{|c|c|c|c|c|c|c|c|c|}
\hline Sample & H0333B & H0693 & H0477 & H1300A & H1300B & D0711 & D0715 & D0873 \\
\hline Sheet_no & L-47-101A & L-47-101A & L-47-101A & L-47-101V & L-47-101V & L-47-101G & L-47-101G & L-47-101B \\
\hline E_coord. $\left({ }^{\circ}\right)$ & 98.19587 & 98.11516 & 98.09348 & 98.00317 & 98.00317 & 98.39088 & 98.43877 & 98.46475 \\
\hline N_coord. $\left(^{\circ}\right)$ & 45.26924 & 45.17224 & 45.17784 & 45.23340 & 45.23340 & 45.27602 & 45.27262 & 45.27620 \\
\hline Rock & amphibolite & metagabbro & amphibolite & amphibolite & amphibolite & amphibolite & amphibolite & gabbro \\
\hline Formation & $\mathrm{CHC}$ & KKC & KKC & KKC & $\mathrm{KKC}$ & UUC & UUC & UUC \\
\hline $\mathrm{SiO}_{2}$ & 43.24 & 46.97 & 43.10 & 46.80 & 47.84 & 48.60 & 51.13 & 48.13 \\
\hline $\mathrm{Al}_{2} \mathrm{O}_{3}$ & 13.64 & 15.65 & 17.64 & 16.43 & 18.11 & 14.18 & 14.08 & 16.05 \\
\hline $\mathrm{Fe}_{2} \mathrm{O}_{3}$ & 14.49 & 12.58 & 13.25 & 11.81 & 12.47 & 12.59 & 11.63 & 13.00 \\
\hline MgO & 7.50 & 8.97 & 3.44 & 6.83 & 4.67 & 8.44 & 7.29 & 7.96 \\
\hline $\mathrm{CaO}$ & 15.41 & 9.17 & 12.45 & 12.11 & 8.85 & 12.09 & 10.44 & 9.39 \\
\hline $\mathrm{Na}_{2} \mathrm{O}$ & 0.53 & 3.22 & 0.95 & 1.69 & 4.04 & 1.75 & 2.34 & 1.35 \\
\hline $\mathbf{K}_{2} \mathbf{O}$ & 0.35 & 0.17 & 1.73 & 0.28 & 0.21 & 0.26 & 0.90 & 1.07 \\
\hline $\mathrm{TiO}_{2}$ & 2.65 & 1.70 & 2.07 & 2.12 & 2.11 & 0.87 & 0.88 & 1.36 \\
\hline $\mathbf{P}_{2} \mathrm{O}_{5}^{2}$ & 0.28 & 0.15 & 0.43 & 0.32 & 0.36 & 0.07 & 0.08 & 0.07 \\
\hline MnO & 0.20 & 0.18 & 0.24 & 0.19 & 0.15 & 0.18 & 0.19 & 0.21 \\
\hline $\mathrm{Cr}_{2} \mathrm{O}_{3}$ & 0.04 & 0.03 & 0.05 & 0.03 & 0.03 & 0.04 & 0.04 & 0.02 \\
\hline LOI & 1.00 & 1.00 & 3.90 & 1.20 & 1.10 & 0.90 & 1.00 & 1.20 \\
\hline TOT_C & 0.04 & 0.05 & 0.95 & 0.02 & 0.05 & 0.08 & 0.06 & 0.03 \\
\hline Total & 99.36 & 99.81 & 99.26 & 99.81 & 99.96 & 99.99 & 100.02 & 99.82 \\
\hline Sc & 44 & 41 & 29 & 34 & 39 & 40 & 38 & 41 \\
\hline $\mathbf{B a}$ & 93.6 & 20.8 & 798.0 & 37.8 & 100.6 & 49.5 & 91.6 & 132.1 \\
\hline $\mathrm{Be}$ & 2 & 1 & 2 & 1 & 1 & 1 & 1 & 2 \\
\hline Co & 62.4 & 48.1 & 39.5 & 40.3 & 47.0 & 51.5 & 43.0 & 54.1 \\
\hline Cs & 0.6 & - & 1.4 & 0.4 & 0.1 & 0.9 & 1.2 & 0.8 \\
\hline Ga & 23.4 & 18.1 & 24.7 & 18.9 & 19.1 & 16.2 & 16.3 & 20.1 \\
\hline Hf & 5.5 & 2.5 & 5.6 & 3.5 & 3.6 & 1.7 & 1.8 & 3.5 \\
\hline Nb & 19.8 & 2.3 & 40.4 & 21.9 & 19.2 & 2.6 & 3.9 & 24.5 \\
\hline $\mathbf{R b}$ & 4.3 & 1.0 & 40.3 & 7.9 & 2.5 & 10.4 & 20.2 & 50.6 \\
\hline Sn & 2 & - & 3 & 1 & 1 & 1 & 1 & 2 \\
\hline $\mathrm{Sr}$ & 508.2 & 518.0 & 332.8 & 449.7 & 281.0 & 252.2 & 153.7 & 311.3 \\
\hline Ta & 1.2 & 0.2 & 2.7 & 1.2 & 1.2 & 0.2 & 0.3 & 1.0 \\
\hline Th & 1.7 & - & 3.4 & 1.8 & 0.8 & 0.6 & 1.8 & 5.1 \\
\hline $\mathbf{U}$ & 1.6 & 0.2 & 1.2 & 0.5 & 0.4 & 0.1 & 0.7 & 0.8 \\
\hline $\mathbf{V}$ & 394 & 323 & 244 & 240 & 287 & 335 & 312 & 308 \\
\hline W & 1.8 & 0.4 & 1.9 & 0.4 & 0.1 & - & 0.4 & 3.8 \\
\hline $\mathrm{Zr}$ & 206.7 & 96.6 & 219.5 & 139.2 & 138.1 & 51.3 & 56.6 & 116.2 \\
\hline Y & 47.4 & 31.9 & 43.4 & 28.5 & 31.9 & 18.1 & 21.4 & 26.6 \\
\hline Mo & 0.2 & 0.2 & 0.7 & 0.2 & 0.8 & - & 0.2 & 0.1 \\
\hline $\mathrm{Cu}$ & 5.4 & 36.4 & 66.5 & 65.2 & 91.3 & 96.7 & 74.9 & 1.9 \\
\hline $\mathbf{P b}$ & 5.9 & 0.3 & 2.4 & 0.6 & 0.3 & 0.9 & 2.4 & 4.3 \\
\hline $\mathbf{Z n}$ & 20 & 19 & 73 & 15 & 34 & 14 & 20 & 27 \\
\hline $\mathrm{Ni}$ & 30.5 & 26.7 & 74.5 & 17.5 & 32.3 & 20.9 & 23.4 & 25.0 \\
\hline As & - & 0.7 & 0.9 & - & - & - & - & - \\
\hline Cd & - & - & 0.1 & - & - & - & - & - \\
\hline Sb & 0.1 & 0.1 & 0.1 & - & - & - & - & - \\
\hline $\mathbf{B i}$ & 2.4 & - & - & - & - & - & 0.1 & 0.3 \\
\hline Au & - & 0.5 & 1.0 & - & 0.7 & 0.7 & 1.3 & 1.4 \\
\hline TI & - & - & 0.1 & - & - & - & - & - \\
\hline La & 17.4 & 4.2 & 32.6 & 14.8 & 12.8 & 3.3 & 4.9 & 18.2 \\
\hline $\mathrm{Ce}$ & 44.5 & 12.6 & 71.7 & 35.5 & 32.3 & 9.1 & 12.4 & 43.1 \\
\hline Pr & 5.77 & 2.14 & 8.15 & 4.53 & 4.36 & 1.34 & 1.70 & 5.16 \\
\hline Nd & 28.6 & 10.5 & 36.9 & 21.7 & 19.5 & 7.3 & 8.0 & 21.7 \\
\hline Sm & 7.1 & 3.7 & 7.5 & 4.9 & 4.8 & 2.1 & 2.5 & 4.8 \\
\hline $\mathbf{E u}$ & 2.29 & 1.54 & 2.63 & 1.68 & 1.50 & 0.77 & 0.76 & 1.20 \\
\hline Gd & 8.55 & 4.69 & 7.33 & 5.05 & 5.28 & 2.53 & 2.91 & 5.13 \\
\hline Tb & 1.28 & 0.97 & 1.19 & 0.88 & 0.95 & 0.49 & 0.59 & 0.88 \\
\hline Dy & 8.15 & 5.40 & 6.98 & 5.04 & 5.14 & 3.27 & 3.58 & 4.65 \\
\hline Ho & 1.74 & 1.15 & 1.43 & 1.05 & 1.11 & 0.57 & 0.66 & 0.83 \\
\hline $\mathbf{E r}$ & 4.59 & 3.44 & 3.89 & 2.97 & 3.26 & 1.93 & 2.05 & 2.64 \\
\hline $\mathbf{T m}$ & 0.60 & 0.47 & 0.55 & 0.41 & 0.47 & 0.25 & 0.30 & 0.39 \\
\hline $\mathbf{Y b}$ & 4.48 & 2.73 & 3.44 & 2.71 & 2.87 & 1.55 & 1.84 & 2.42 \\
\hline Lu & 0.64 & 0.47 & 0.58 & 0.39 & 0.42 & 0.26 & 0.30 & 0.35 \\
\hline$\sum$ REE & 135.69 & 54.00 & 184.87 & 101.61 & 94.76 & 34.76 & 42.49 & 111.45 \\
\hline
\end{tabular}


representing a roof pendant to the Unegt Uul metagranite and two amphibolites, which are likely tectonic fragments incorporated into the UUC by the activity of the Bogt fault.

The $\mathrm{P}-\mathrm{T}$ conditions were calculated for marginal parts of the mineral grains, which seem to be well equilibrated. Additionally, wherever possible, independent estimates were obtained for central parts of garnet grains taking the included minerals into account. The aim was to estimate $\mathrm{P}-\mathrm{T}$ conditions for the early and late stages of metamorphism.

The amphibolites are represented by two garnetbearing samples H0256 and H0159. The sample H0256 consists of amphibole, garnet, plagioclase and biotite; titanite and opaque minerals are accessoric. Amphibole
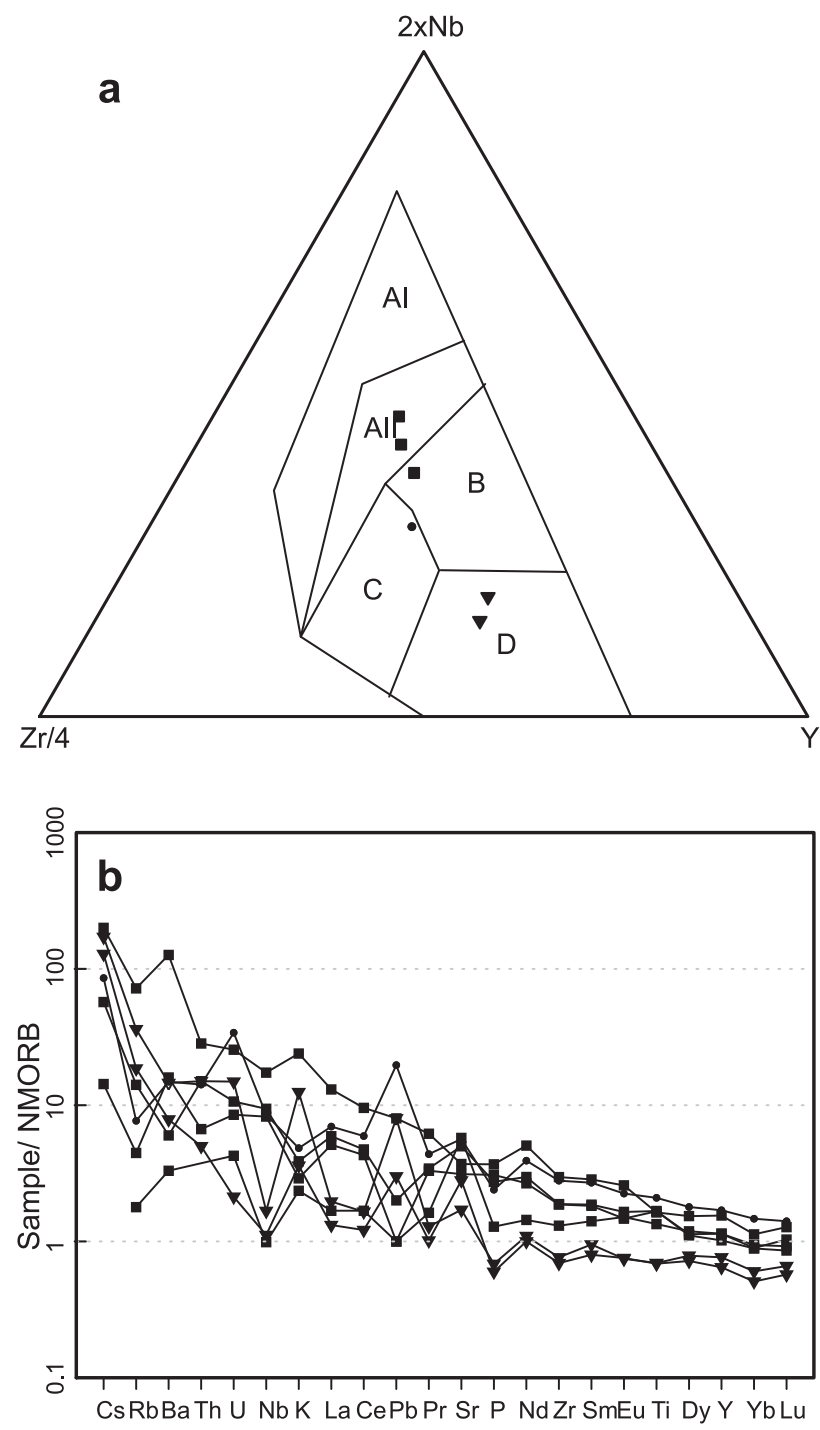

corresponding to ferrotschermakite (Leake et al. 1997) has $\mathrm{X}_{\mathrm{Mg}}=0.24$ in the centres of the crystals and slightly higher $\mathrm{X}_{\mathrm{Mg}}=0.25$ in the marginal parts. Garnet grains show zoning from $\mathrm{Alm}_{61} \operatorname{Sps}_{3} \operatorname{Prp}_{3} \mathrm{Grs}_{31}$ in cores to Alm 61 $\mathrm{Sps}_{0.5} \operatorname{Prp}_{2-3} \mathrm{Grs}_{34}$ at the rims (Fig. 5a). Plagioclase has labradorite composition $\left(\mathrm{An}_{60-62}\right)$. Biotite in matrix $\left(\mathrm{Al}^{\mathrm{IV}}=\right.$ 2.75 and $\mathrm{X}_{\mathrm{Fe}}=0.73$ ) differs slightly from that included in garnet grains $\left(\mathrm{Al}^{\mathrm{IV}}=2.48\right.$ and $\left.\mathrm{X}_{\mathrm{Fe}}=0.74\right)$.

The sample H0159 contains garnet with compositional zoning from $\mathrm{Alm}_{57} \mathrm{Sps}_{7} \operatorname{Prp}_{7-8} \mathrm{Grs}_{27}$ in the central parts to $\mathrm{Alm}_{56} \mathrm{Sps}_{1-2} \operatorname{Prp}_{11} \mathrm{Grs}_{28-29}$ in the rims (Fig. 5b). Plagioclases are labradorite $\left(\mathrm{An}_{53-54}\right)$. Amphiboles correspond to ferrotschermakite with $\mathrm{X}_{\mathrm{Mg}}=0.39$.

The metamorphic conditions calculated using THERMOCALC (Powell and Holland 1985) from amphibolites suggest a prograde growth at progressively increasing temperature, the central parts together with included grains giving $\mathrm{T}=613 \pm 90{ }^{\circ} \mathrm{C} ; \mathrm{P}=6.4 \pm 1.1$. Marginal parts yield conditions of $761 \pm 79{ }^{\circ} \mathrm{C} ; 6.2 \pm 1.4 \mathrm{kbar}, 753$ $\pm 87^{\circ} \mathrm{C} ; 6.4 \pm 1.6 \mathrm{kbar}$ and $\mathrm{T}=655 \pm 46^{\circ} \mathrm{C}$ and $\mathrm{P}=7.5$ \pm 0.9 kbar (Tab. 3, Figs 9a, 10).

The conventional garnet-amphibole thermometer of Ravna (2000), also used for estimating the metamorphic conditions, shows slightly lower temperatures then Thermocalc calculations. The temperatures calculated for the rims in the sample H0256 yield values of 753 and $687^{\circ} \mathrm{C}$. The temperatures calculated for the sample $\mathrm{H} 0159$ from the central parts of mineral grains correspond to $490-554{ }^{\circ} \mathrm{C}$, for marginal parts to $561{ }^{\circ} \mathrm{C}$ (Tab. 5).

The mica schists are represented by the sample H0161. Its mineral association comprises quartz, muscovite, biotite, garnet and plagioclase; zircon and apatite are accessoric. The garnet zoning ranges between $\mathrm{Alm}_{67-69}$

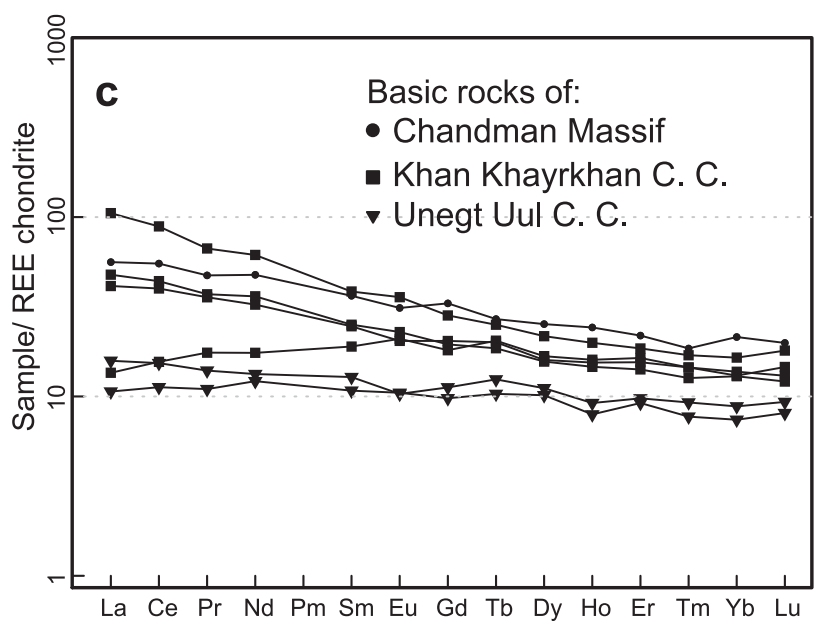

Fig. 8 Geochemical characteristics of the basic rocks from the individual crystalline complexes a - ternary diagram $\mathrm{Zr} / 4-2 \times \mathrm{Nb}-\mathrm{Y}$ for geotectonic discrimination of basaltic rocks (Meschede 1986), AI - Within-plate alkali basalt, AII - Within-plate alkali basalt, Within-plate tholeiite, B - Enriched Mid-ocean ridge basalt, C - Volcanic arc basalt, D - Normal Mid-ocean ridge basalt ; b - trace-element multielement plots (normalized to N-MORB after Sun and McDonough 1989); $\mathbf{c}$ - characteristic REE patterns (normalized to average chondrite composition after Boynton 1984). 

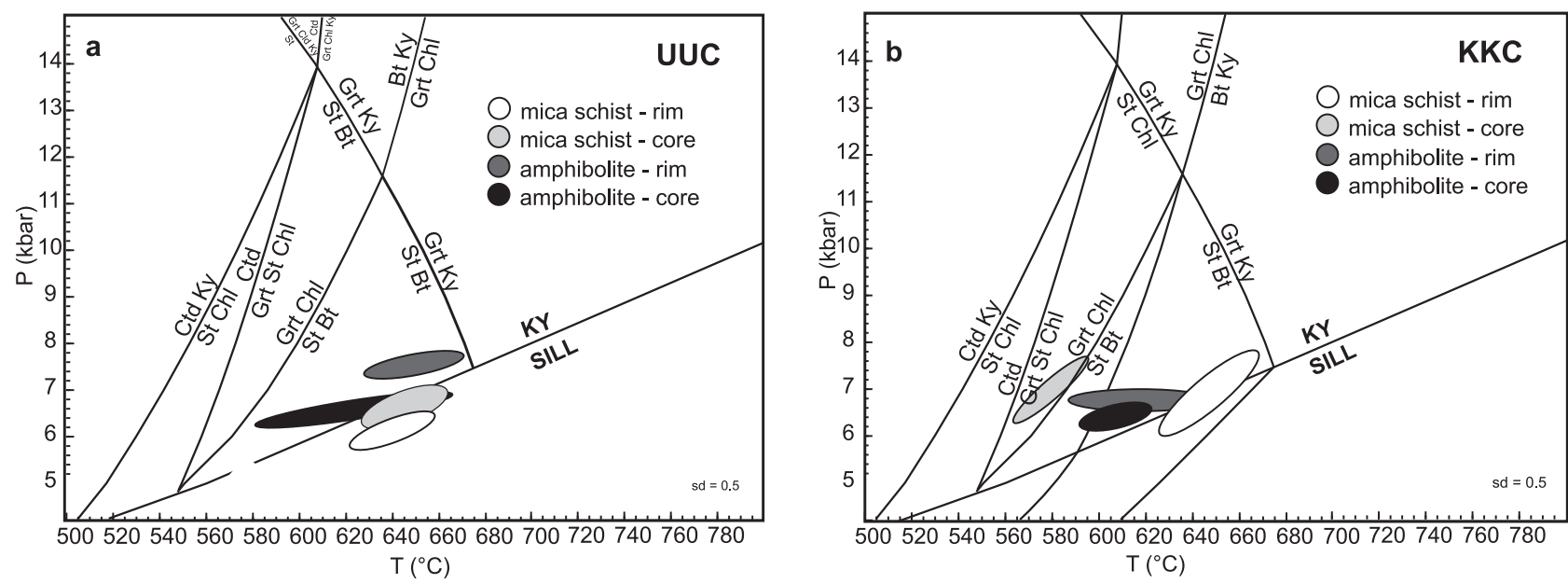

Fig. 9 P-T grid for samples of amphibolitic rocks and metapelites from a - Unegt Uul Crystalline Complex; $\mathbf{b}-$ Khan Khayrkhan Crystalline Complex.

$\mathrm{Sps}_{20} \operatorname{Prp}_{6} \mathrm{Grs}_{3-6}$ in the cores and $\mathrm{Alm}_{66} \mathrm{Sps}_{25} \operatorname{Prp}_{5} \mathrm{Grs}_{2}$ in the rims (Fig. 5c). In contrast to the garnet grains in the amphibolites of the same unit, they show more retrograde character documented by rimward increase in Sps and decrease in Prp components. Plagioclases show also slightly different character in centres of the grains, where they have $\mathrm{An}_{28}$. The marginal parts of plagioclases correspond to $\mathrm{An}_{24}$.

The $\mathrm{P}-\mathrm{T}$ estimates computed from mica schist seem to be relatively constant for the central and marginal parts of the mineral grains, which suggests a likely faster mineral growth at $\mathrm{T}$ ranging from $639 \pm 30$ to $657 \pm 33{ }^{\circ} \mathrm{C}$ and $\mathrm{P}$ from $6 \pm 1.2$ to $6.7 \pm 1.2 \mathrm{kbar}$ (Tab. 3, Figs 9a, 10).

For the comparison, the garnet-biotite thermometers were also used for calculating temperatures in mica schists. Five different thermometers were employed (Thompson 1976; Lee and Holdaway 1977; Ferry and Spear 1978; Perchuk and Lavrent'eva 1983; Bhattacharya et al. 1992). The results differ in order of tens of degrees, as summarized in Tab. 4.

The temperatures in mica schists at 6 kbar reach 516$622{ }^{\circ} \mathrm{C}$ in marginal parts of the garnet grains and span $508-665{ }^{\circ} \mathrm{C}$ in the cores. These are in agreement with THERMOCALC results, showing no significant temperature differences between cores and rims.

\subsection{Chandman Khayrkhan Crystalline Complex}

The widespread migmatitization probably bears witness to peak metamorphic conditions. The migmatitization may be related to the pre-intrusive metamorphic event or it may be a result of periplutonic metamorphism linked with the high-T regime during granite emplacement of the Chandman Massif.

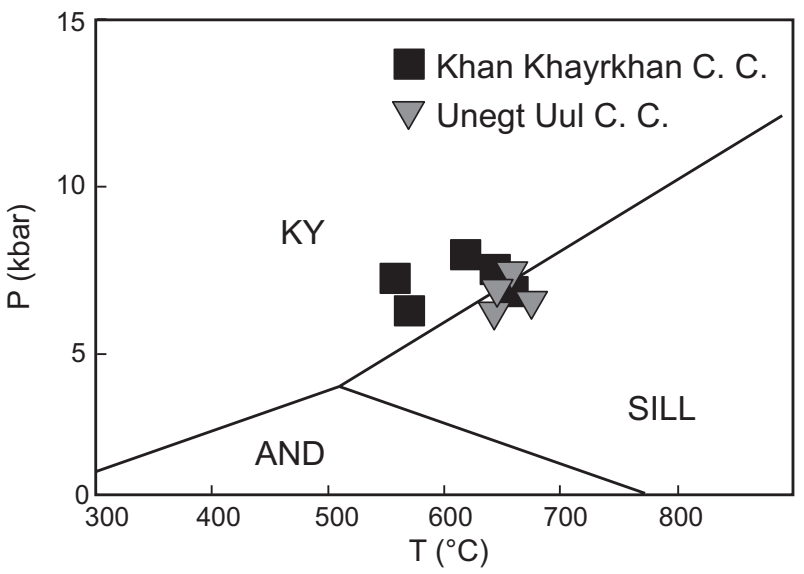

Fig. 10 Correlation of calculated P-T conditions of samples from Unegt Uul Crystalline Complex and Khan Khayrkhan Crystalline Complex units.

Subsequently the rocks of the CHC were strongly affected by a younger retrograde metamorphic event. Mineral assemblage in the calc-silicate rocks (Ep + Act $+\mathrm{Pl}$ ) is probably a product of retrograde metamorphism under the lower amphibolite to greenschist-facies conditions $\left(<600{ }^{\circ} \mathrm{C}\right.$ for $5 \mathrm{kbar}-$ Thompson and Norton 1968). Mineral assemblage observed in the studied rocks however precludes a more accurate $\mathrm{P}-\mathrm{T}$ calculation.

\subsection{Khan Khayrkhan Crystalline Complex}

Metamorphism in the Khan Khayrkhan Crystalline Complex was studied on samples of mica schists and garnetbearing amphibolites.

Mica schists are represented by samples H0478 and H0477. Sample H0478 comprises mineral assemblage $\mathrm{Grt}+\mathrm{Bt}+\mathrm{St}+\mathrm{Pl}$. Garnet zoning (Fig. 6a) varies from 
Tab. 3 Results of P-T calculations using Thermocalc. The results falling outside the sigfit limit are shown in grey.

\begin{tabular}{|c|c|c|c|c|c|c|c|c|c|c|}
\hline Sample & Position & Unit & Rock & av $\mathrm{T}^{\circ} \mathrm{C}$ & $\mathrm{sd}(\mathrm{T})$ & P (kbar) & $\mathrm{sd}(\mathrm{P})$ & corr & sigfit & $\begin{array}{l}\text { fit for } 95 \% \\
\text { confidence }\end{array}$ \\
\hline H0256 & core & UUC & amphibolite & 613 & 90 & 6.4 & 1.1 & 0.888 & 1.20 & 1.54 \\
\hline H0256 & rim & UUC & amphibolite & 761 & 79 & 6.2 & 1.4 & 0.192 & 1.30 & 1.45 \\
\hline H0256 & rim & UUC & amphibolite & 753 & 87 & 6.4 & 1.6 & 0.056 & 1.34 & 1.45 \\
\hline H0159 & rim & UUC & amphibolite & 655 & 46 & 7.5 & 0.9 & 0.592 & 1.10 & 1.45 \\
\hline H0161 & core & UUC & mica schist & 647 & 31 & 6.7 & 1.2 & 0.724 & 0.44 & 1.61 \\
\hline H0161 & core & UUC & mica schist & 657 & 33 & 6.6 & 1.4 & 0.693 & 0.81 & 1.61 \\
\hline H0161 & rim & UUC & mica schist & 639 & 30 & 6.0 & 1.2 & 0.730 & 0.65 & 1.61 \\
\hline H0478 & core & $\mathrm{KKC}$ & mica schist & 559 & 33 & 7.4 & 1.6 & 0.944 & 0.11 & 1.73 \\
\hline H0478 & rim & $\mathrm{KKC}$ & mica schist & 608 & 36 & 7.9 & 1.5 & 0.947 & 0.90 & 1.61 \\
\hline H0478 & rim & $\mathrm{KKC}$ & mica schist & 639 & 22 & 7.5 & 0.8 & 0.235 & 0.41 & 1.61 \\
\hline H0477 & core & $\mathrm{KKC}$ & mica schist & 651 & 47 & 7.2 & 2.9 & 0.929 & 0.40 & 1.73 \\
\hline H0477 & rim & KKC & mica schist & 636 & 47 & 7.9 & 3.1 & 0.933 & 0.24 & 1.73 \\
\hline H0357 & rim & KKC & amphibolite & 575 & 24 & 6.2 & 1.6 & 0.183 & 1.71 & 1.42 \\
\hline H0357 & rim & $\mathrm{KKC}$ & amphibolite & 578 & 69 & 6.4 & 1.5 & 0.533 & 1.34 & 1.54 \\
\hline H0478B & rim & $\mathrm{KKC}$ & amphibolite & 683 & 97 & 6.7 & 2.4 & 0.614 & 1.68 & 1.61 \\
\hline H0478B & core & $\mathrm{KKC}$ & amphibolite & 587 & 109 & 6.2 & 2.6 & -0.119 & 2.16 & 1.54 \\
\hline
\end{tabular}

composition $\mathrm{Alm}_{73} \mathrm{Sps}_{0-1} \operatorname{Prp}_{10-11} \mathrm{Grs}_{14}$ in cores to $\mathrm{Alm}_{72}$ $\mathrm{Sps}_{1} \operatorname{Prp}_{14-15} \mathrm{Grs}_{11-12}$ in rims. Biotite has $\mathrm{Al}^{\mathrm{IV}}=2.42$ and $\mathrm{X}_{\mathrm{Fe}}=0.50-0.51$ in contact with garnet, the values of $\mathrm{Al}^{\mathrm{IV}}=$ 2.38 and $\mathrm{X}_{\mathrm{Fe}}=0.46-0.47$ are characteristic of biotites from matrix and $\mathrm{Al}^{\mathrm{IV}}=2.5$ with $\mathrm{X}_{\mathrm{Fe}}=0.43-0.45$ have biotites in contact with staurolite. Staurolite is Fe staurolite with $\mathrm{X}_{\mathrm{Fe}}$ $=0.87-0.89$. Plagioclase corresponds to andesine $\left(\mathrm{An}_{37}\right)$. Alumosilicate kyanite is present in comparable mica schist samples which, unfortunately, were not analysed.

Sample H0477 has mineral assemblage $\mathrm{Mu}+\mathrm{Bt}+\mathrm{St}$ $+\mathrm{Pl}$. Plagioclase is oligoclase with $\mathrm{An}_{24-27}, \mathrm{X}_{\mathrm{Fe}}$ in staurolite is 0.86-0.89; biotites have $\mathrm{Al}^{\mathrm{IV}}=2.42-2.46$ and $\mathrm{X}_{\mathrm{Fe}}$ $=0.46-0.50$.

Thermocalc P-T calculations for the samples of mica schists yielded conditions varying from c. $559 \pm 33$ to $651 \pm 47{ }^{\circ} \mathrm{C}$ and from $7.2 \pm 2.9$ to $7.4 \pm 1.6 \mathrm{kbar}$ for the central parts of garnet porphyroblasts and from $636 \pm$ $47^{\circ} \mathrm{C}$ to $639 \pm 22^{\circ} \mathrm{C}$ and from $7.5 \pm 0.8$ to $7.9 \pm 1.5 \mathrm{kbar}$ for the rims. The peak metamorphic assemblage was $\mathrm{Bt}$ $+\mathrm{Ms}+\mathrm{Grt} \pm \mathrm{St} \pm \mathrm{Ky}$. However, these $\mathrm{P}-\mathrm{T}$ conditions seem to be rather high for mentioned mineral assemblage. Similar conditions were obtained also using garnet-biotite thermometer, which yielded temperatures from 654 to $715^{\circ} \mathrm{C}$ for the rims of mineral grains, setting $\mathrm{P}=6 \mathrm{kbar}$ (Tab. 4).

Amphibolite samples H0357 and H0478B were also used for P-T calculations. Mineral association of $\mathrm{H} 0357$ includes ferrotschermakite $\left(\mathrm{X}_{\mathrm{Mg}}=0.42-0.49\right)$, biotite $\left(\mathrm{Al}^{\mathrm{IV}}=2.52-0.60\right.$ and $\left.\mathrm{X}_{\mathrm{Fe}}=0.43-0.55\right)$, garnet (with compositional zoning from $\mathrm{Alm}_{65} \mathrm{Sps}_{8} \operatorname{Prp}_{10} \mathrm{Grs}_{15}$ in cores to $\operatorname{Alm}_{64} \operatorname{Sps}_{7} \operatorname{Prp}_{12} \operatorname{Grs}_{15}$ at the rims) and labradorite $\left(\mathrm{An}_{52-65}\right)$.

Tab. 4 Results of P-T calculations using garnet-biotite thermometers according to Thompson (1976), Lee and Holdaway (1977), Ferry and Spear (1978), Perchuk and Lavrent'eva (1983) and Bhattacharya et al. (1992).

\begin{tabular}{|c|c|c|c|c|c|c|c|c|c|}
\hline \multirow[b]{2}{*}{ Sample } & \multirow[b]{2}{*}{ Position } & \multirow[b]{2}{*}{ Unit } & \multirow[b]{2}{*}{ Rock } & \multicolumn{6}{|c|}{ Temperature ${ }^{\circ} \mathrm{C}$} \\
\hline & & & & $\mathrm{P}$ (kbar) & $\begin{array}{l}\text { Bhatacharya } \\
\text { et al. (1992) }\end{array}$ & $\begin{array}{c}\text { Ferry and } \\
\text { Spear (1978) }\end{array}$ & $\begin{array}{c}\text { Perchuk and } \\
\text { Lavrent' eva } \\
\quad(1983)\end{array}$ & $\begin{array}{c}\text { Thompson } \\
\text { (1976) }\end{array}$ & $\begin{array}{c}\text { Lee and } \\
\text { Holdaway } \\
(1977)\end{array}$ \\
\hline H0161 & rim & $\mathbf{U U C}$ & micaschist & 6 & 544 & 612 & 602 & 626 & 602 \\
\hline H0161 & rim & $\mathbf{U U C}$ & micaschist & 6 & 516 & 581 & 585 & 602 & 581 \\
\hline H0161 & core & $\mathbf{U U C}$ & micaschist & 6 & 570 & 658 & 626 & 665 & 633 \\
\hline H0478 & rim & KKC & micaschist & 6 & 682 & 715 & 654 & 703 & 668 \\
\hline
\end{tabular}


Mineral assemblage of the sample H0478B is fairly similar and involves garnet, amphibole and plagioclase. Garnet zoning varies from $\mathrm{Alm}_{73} \mathrm{Sps}_{3} \operatorname{Prp}_{9} \mathrm{Grs}_{10}$ in central part of grains to $\mathrm{Alm}_{72} \mathrm{Sps}_{0.8} \operatorname{Prp}_{13} \mathrm{Grs}_{11}$ in the rim. Composition of amphibole slightly differs in the cores $\left(\mathrm{X}_{\mathrm{Mg}}=0.40\right)$ from the rims $\left(\mathrm{X}_{\mathrm{Mg}}=0.37\right)$. Plagioclase with normal zoning from this sample corresponds to andesine $\left(\mathrm{An}_{35}\right)$.

Metamorphic conditions estimated from amphibolites indicate an evolution similar to that of mica schists. Results of THERMOCALC calculations for amphibolite H0478B correspond to $\mathrm{T}=587 \pm 109^{\circ} \mathrm{C}$ and $\mathrm{P}=6.2 \mathrm{kbar}$ for the mineral cores, slightly higher conditions $683 \pm 97{ }^{\circ} \mathrm{C}$ and $6.7 \pm 2.4 \mathrm{kbar}$ were calculated for the rims. Using THERMOCALC, the sample H0357 yielded temperatures of 575 and $578{ }^{\circ} \mathrm{C}$ at pressures of 6.2 and $6.4 \mathrm{kbar}$ for the marginal parts of measured mineral grains. Garnet-amphibole thermometer (Ravna 2000) gave $\mathrm{T}=617$ and $514{ }^{\circ} \mathrm{C}$ (Tab. 5). Both temperatures correspond to the marginal parts of the mineral grains.

The contrast between $\mathrm{P}-\mathrm{T}$ conditions estimated from central and marginal parts of the grains as well as (although indistinctive) zoning in $\operatorname{Prp}$ and Sps components across the garnet grains provide an evidence for prograde metamorphism (Tab. 3, Figs. 9b, 10).

\section{Dating}

\subsection{Unegt Uul Crystalline Complex}

Two grains of slightly cloudy zircon, with rectangular shape $(c .80 \times 160 \mu \mathrm{m})$, have been recovered from leucogranite H0057. The grain zr1 is characterized by a sector zoning with only relict oscillatory banding (Fig. 11a), while in zr2 the fine oscillatory zoning, with darker core and lighter mantle, is well preserved. Four LA-ICP-MS spots on each grain give contrasting results (Tabs 6,9); zr1 analyses define an upper intercept of $329 \pm 33 \mathrm{Ma}$, which is consistent with the concordia age of $337 \pm 6$ $\mathrm{Ma}$ (Early Carboniferous) from two concordant spots. In contrast all analyses from zr2 yield a concordia age of $518 \pm 5 \mathrm{Ma}$ (Early Cambrian). The contrasting ages are difficult to interpret given the small number of analyzed grains and that the leucogranite shows no clear signs of a metamorphic overprint. The age of $c .518$ Ma most likely dates the time of zr2 crystallization, which could be related to the leucogranite formation. The meaning of the c. $337 \mathrm{Ma}$ age remains, however, unclear.

\subsection{Chandman Khayrkhan Crystalline Complex}

These metamorphic rocks have not been successfully dated in the frame of the project, the data obtained from this part of the studied area come from granitoid rocks of the Chandman Massif only. The monazite from granite was dated using the CHIME technique. Only one monazite grain could be measured and thus it is essential to consider the credibility of such an individual measurement. The measured monazite was yellowish short prismatic with length of 80-120 $\mu \mathrm{m}$. No metamictization effects have been observable under CL. The data obtained point to an age of $332 \pm 29 \mathrm{Ma}(\mathrm{MSWD}=0.20)$, which corresponds to Late Carboniferous.

The LA-ICP-MS U-Pb dating of zircons from the Chandman granite yields concordia age of $345 \pm 2 \mathrm{Ma}$ (2б) (Tabs 7, 9; Fig. 11b). Together with 6 discordant analyses they define a discordia with intercepts at $354 \pm 26$ and $154 \pm 160 \mathrm{Ma}$ or with an upper intercept of

Tab. 5 Results of P-T calculations using garnet-amphibole thermometer according to Ravna (2000)

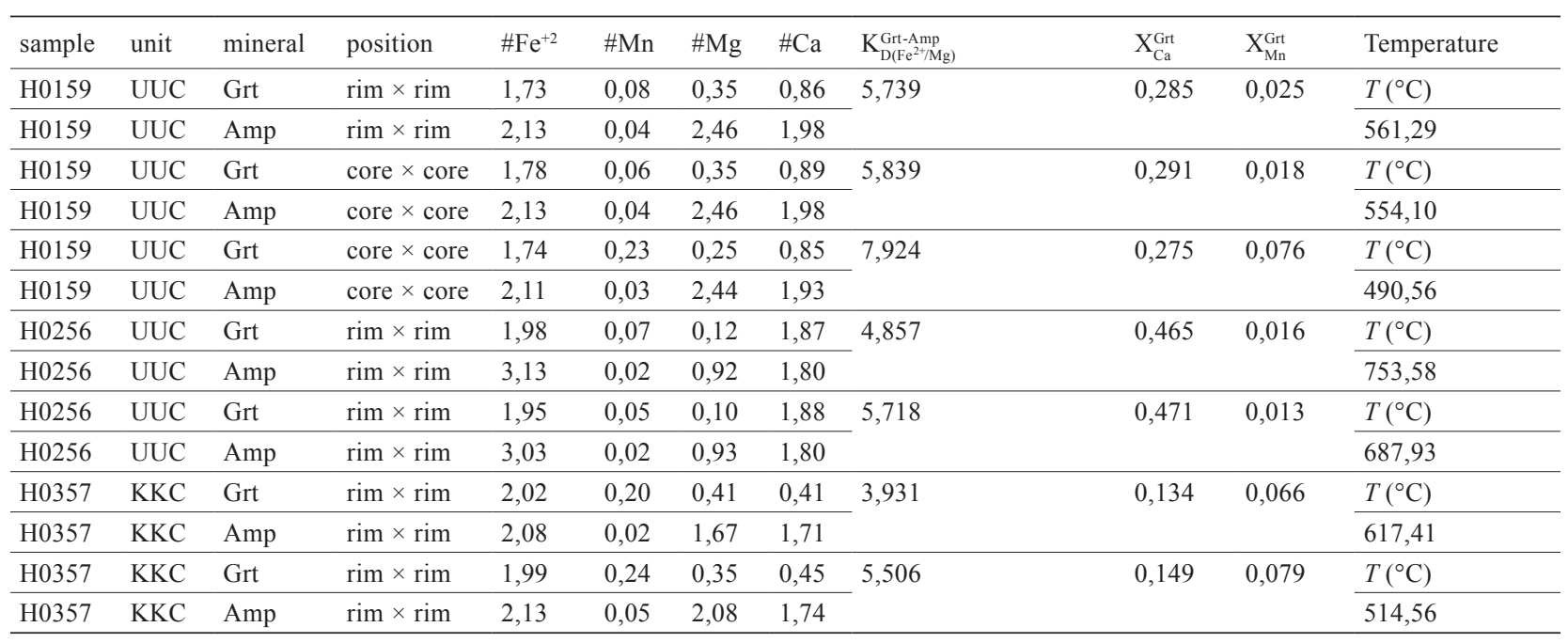




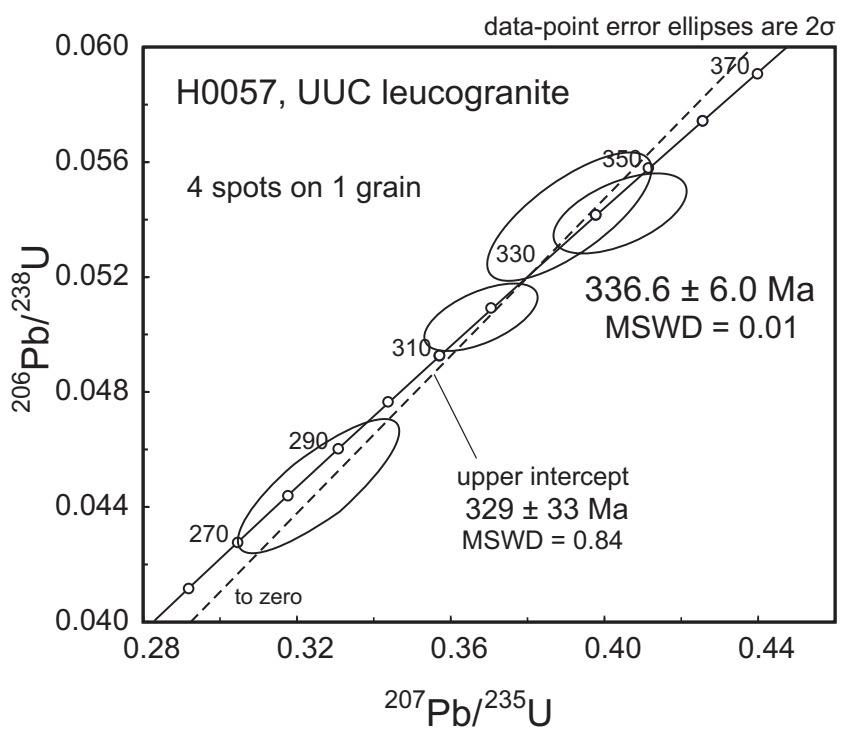

data-point error ellipses are $2 \sigma$

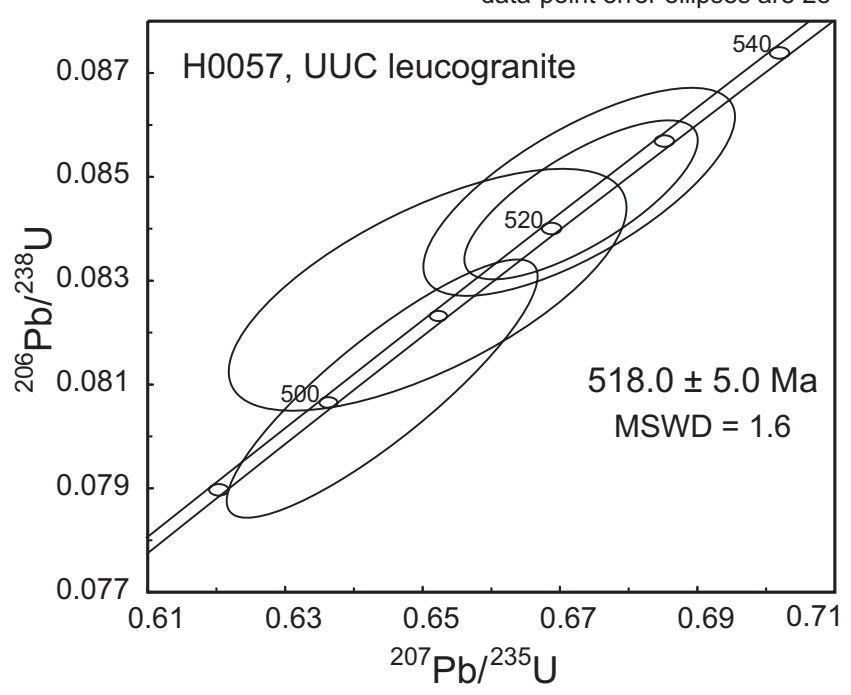

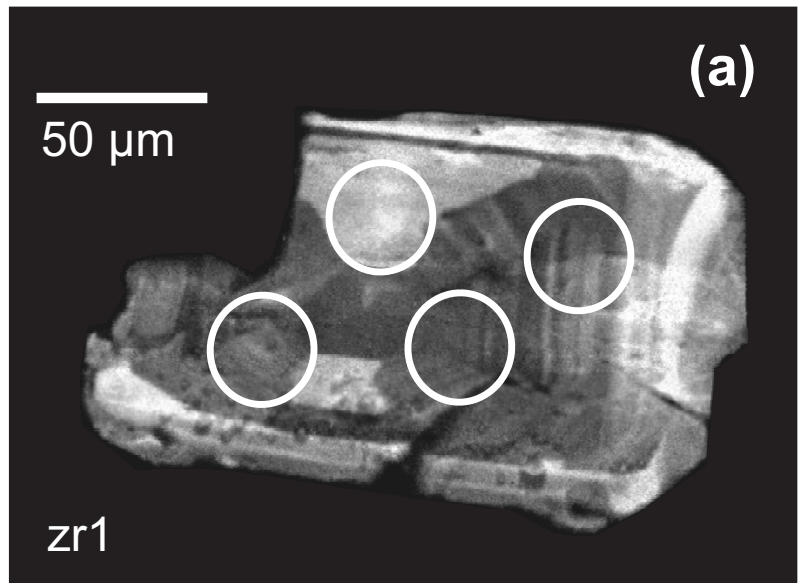

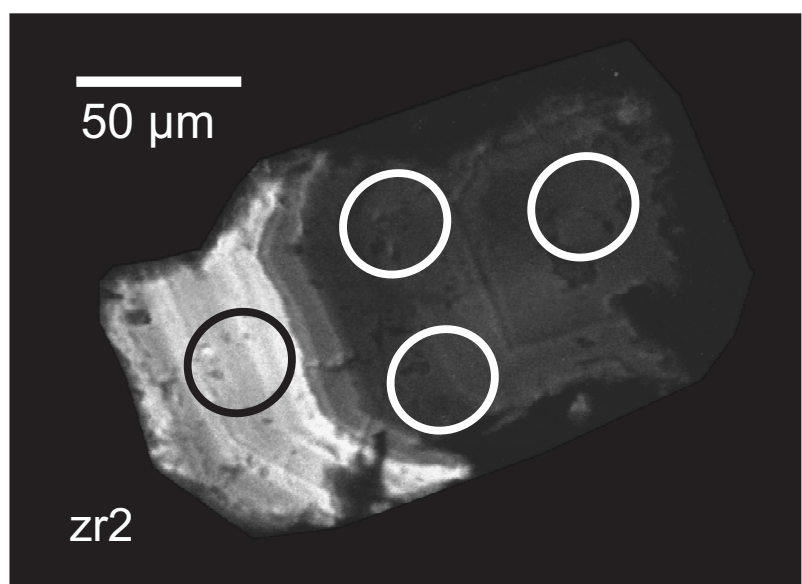

Fig. 11a Position of analyzed points in zircon grains and calculated concordia ages for Unegt Uul Crystalline Complex.

$346 \pm 12$ Ma when forced through zero. The age of $345 \pm$ $2 \mathrm{Ma}$ (Early Carboniferous) is therefore interpreted as the best estimate for the time of granite crystallization.

\subsection{Khan Khayrkhan Crystalline Complex}

Zircons from the sample R0237 (leucocratic orthogneiss) are clear to cloudy, yellowish, and short to long prismatic with aspect ratios of $1: 1$ to $3: 1$ and length of 150-350 $\mu \mathrm{m}$ (Fig. 11c). Twenty-six U-Pb spot analyses were carried out on 24 grains. The $U$ contents range from 100 to $c$. $2000 \mathrm{ppm}$, while the $\mathrm{Th} / \mathrm{U}$ ratios vary only from 0.40 to 1.00 . Cracks are abundant in most grains. Oscillatory zoning predominates in the CL images. It is well-defined in the outer domains while the inner parts of various grains are characterized by chaotic zoning, an almost uniform grey luminescence, or a combination of both. This is consistent with multiphase zircon growth, in which the earlier zoning was variously obliterated due to a later crystallization event. The latter was dated by 24 spots, which define a discordia with intercepts at 362 $\pm 17 \mathrm{Ma}$ and around zero. Only 10 of the spots yield concordant results with a concordia age of $363 \pm 3 \mathrm{Ma}$ (Tabs 8-9). The high percentage of discordant analyses relates to $\mathrm{Pb}$-loss due to radiation damage. This is supported by a clear correlation between the degree of discordance and the $U$ content $\left(r^{2}=0.60\right)$. Two spots yielded older, apparently concordant $\mathrm{U}-\mathrm{Pb}$ ages of around 529 and 591 

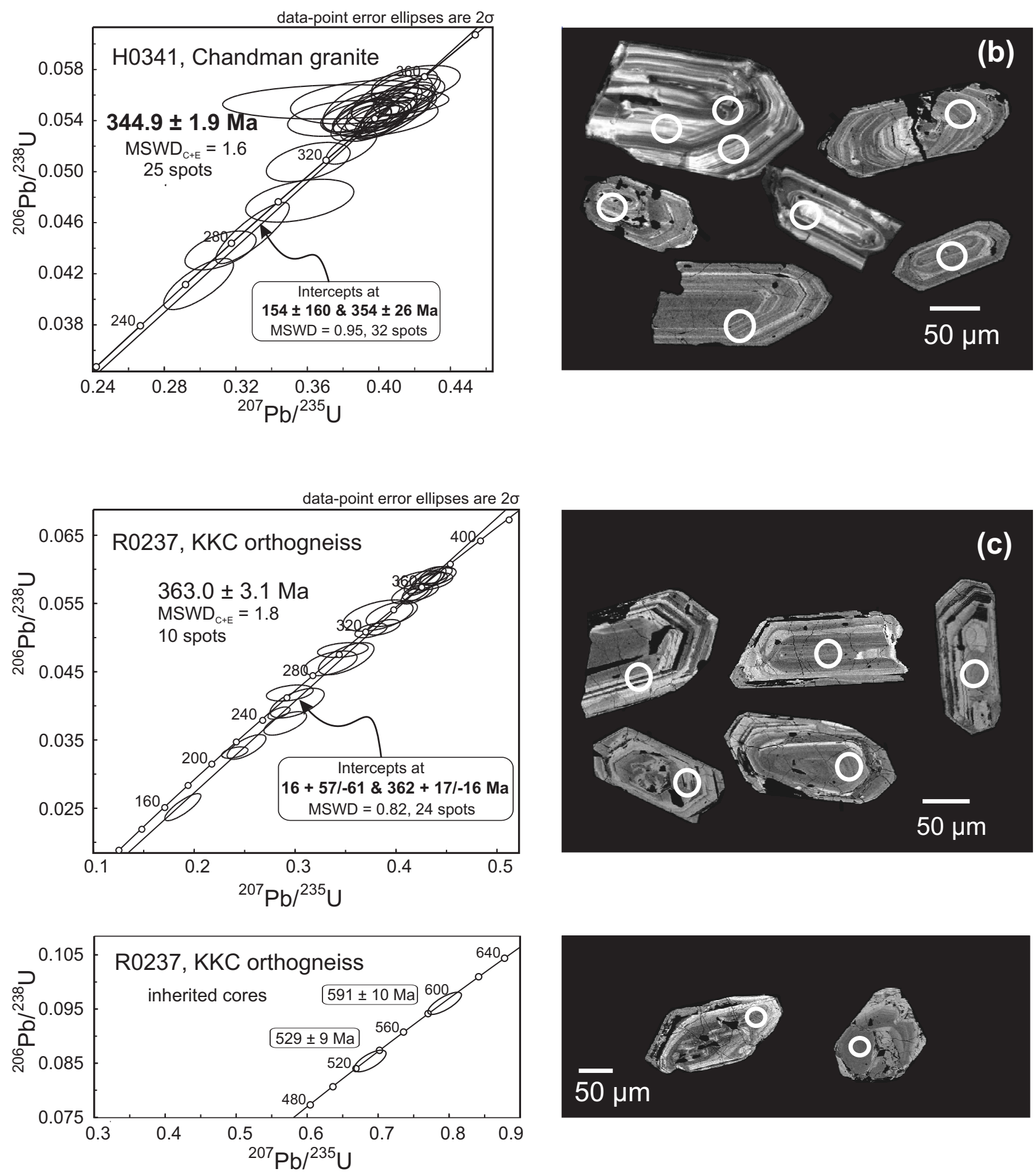

Fig. 11b, $\mathbf{c}$ Position of analyzed points in zircon grains and calculated concordia ages for b-Chandman Massif; $\mathrm{c}-$ Khan Khayrkhan Crystalline Complex.

Ma, respectively. Thus in most analyzed grains inherited domains have been fully reset during re-crystallization or were not present. The age of $363 \pm 3 \mathrm{Ma}$ (the latest Devo- nian) is interpreted as the time of granite crystallization, while the cores probably record Cambrian inheritance in the granite protolith. 
Tab. 6 LA-ICP-MS U, Pb and Th isotope data of dated zircon grains from sample H0057, Unegt Uul Crystalline Complex.

\begin{tabular}{|c|c|c|c|c|c|c|c|c|c|c|c|c|c|c|c|c|c|c|}
\hline \multirow{3}{*}{ No. } & \multicolumn{11}{|c|}{ Isotope ratios ${ }^{\mathrm{c}}$} & \multirow{3}{*}{ rho $^{\mathrm{d}}$} & \multicolumn{6}{|c|}{ Ages (Ma) } \\
\hline & ${ }^{207} \mathrm{~Pb}^{\mathrm{a}}$ & $\mathrm{U}^{\mathrm{b}}$ & $\mathrm{Pb}^{\mathrm{b}}$ & $\mathrm{Th}^{\mathrm{b}}$ & ${ }^{206} \mathrm{~Pb}$ & ${ }^{206} \mathrm{~Pb}^{*}$ & $\pm 2 \sigma$ & ${ }^{207} \mathrm{~Pb}^{*}$ & $\pm 2 \sigma$ & ${ }^{207} \mathrm{~Pb}^{*}$ & $\pm 2 \sigma$ & & ${ }^{207} \mathrm{~Pb}$ & & ${ }^{206} \mathrm{~Pb}$ & & ${ }^{207} \mathrm{~Pb}$ & \\
\hline & (cps) & $(\mathrm{ppm})$ & $(\mathrm{ppm})$ & $\overline{\mathrm{U}}$ & ${ }^{204} \mathrm{~Pb}$ & ${ }^{238} \mathrm{U}$ & $(\%)$ & $\overline{{ }^{235} \mathrm{U}}$ & $(\%)$ & $\overline{{ }^{206} \mathrm{~Pb}^{*}}$ & $(\%)$ & & $\overline{{ }^{235} \mathrm{U}}$ & $\pm 2 \sigma$ & ${ }^{238} \mathrm{U}$ & $\pm 2 \sigma$ & $\overline{{ }^{206} \mathrm{~Pb}}$ & $\pm 2 \sigma$ \\
\hline \multicolumn{19}{|c|}{ sample H0057, leucogranite } \\
\hline $\mathrm{zr} 1-\mathrm{a}$ & 837 & 186 & 13.1 & 1.60 & 1589 & 0.05411 & 3.4 & 0.3917 & 4.5 & 0.05250 & 3.0 & 0.75 & 340 & 12 & 336 & 30 & 307 & 67 \\
\hline $\mathrm{zr} 1-\mathrm{b}$ & 2702 & 155 & 10.0 & 1.52 & 5030 & 0.05055 & 1.9 & 0.3689 & 3.3 & 0.05292 & 2.6 & 0.59 & 318 & 6 & 319 & 21 & 325 & 60 \\
\hline $\mathrm{zr} 1-\mathrm{c}$ & 1989 & 172 & 11.7 & 1.42 & 3605 & 0.05341 & 2.2 & 0.3988 & 3.6 & 0.05415 & 2.9 & 0.60 & 335 & 7 & 341 & 25 & 377 & 65 \\
\hline zr1-d & 932 & 93 & 5.1 & 1.03 & 1719 & 0.04472 & 4.3 & 0.3263 & 5.3 & 0.05292 & 3.1 & 0.81 & 282 & 12 & 287 & 31 & 325 & 71 \\
\hline zr2-a & 12517 & 390 & 36 & 0.94 & 184 & 0.08281 & 2.4 & 0.6522 & 3.7 & 0.05712 & 2.8 & 0.65 & 513 & 12 & 510 & 38 & 496 & 62 \\
\hline zr2-b & 14545 & 872 & 85 & 0.90 & 24734 & 0.08451 & 1.6 & 0.6745 & 2.1 & 0.05788 & 1.4 & 0.75 & 523 & 8 & 523 & 22 & 525 & 31 \\
\hline $\mathrm{zr} 2-\mathrm{c}$ & 10150 & 637 & 60 & 0.88 & 7558 & 0.08097 & 2.6 & 0.6456 & 3.0 & 0.05783 & 1.4 & 0.88 & 502 & 13 & 506 & 30 & 523 & 31 \\
\hline zr2-d & 5204 & 566 & 50 & 0.41 & 8595 & 0.08471 & 2.1 & 0.6739 & 2.8 & 0.05770 & 1.9 & 0.73 & 524 & 11 & 523 & 30 & 518 & 42 \\
\hline Plesovi ${ }^{\mathrm{e}}$ & 6982 & 732 & 37 & 0.12 & 11233 & 0.05397 & 1.5 & 0.3972 & 1.6 & 0.05338 & 0.5 & 0.74 & 339 & 5 & 340 & 5 & 345 & 11 \\
\hline
\end{tabular}

a within-run background-corrected mean ${ }^{207} \mathrm{~Pb}$ signal in counts per seconds. ${ }^{\mathbf{b}} \mathrm{U}$ and $\mathrm{Pb}$ content and $\mathrm{Th} / \mathrm{U}$ ratio were calculated relative to GJ-1 reference and are accurate to approximately $10 \%$ due to heterogeneity of the GJ-1 zircon. ${ }^{\mathbf{c}}$ corrected for background, mass bias, laser induced $\mathrm{U}-\mathrm{Pb}$ fractionation and common $\mathrm{Pb}$ using Stacey and Kramers (1975) model $\mathrm{Pb}$ composition. ${ }^{207} \mathrm{~Pb} /{ }^{235} \mathrm{U}$ calculated using ${ }^{207} \mathrm{~Pb} /{ }^{206} \mathrm{~Pb} /\left({ }^{238} \mathrm{U} /{ }^{206} \mathrm{~Pb} \times\right.$ 1/137.88). Uncertainties are propagated by quadratic addition of within-run precision (2SE) and the reproducibility of GJ-1 (2SD). ${ }^{\mathbf{d}}$ Rho is the error correlation defined as $\operatorname{err}^{206} \mathrm{~Pb} /{ }^{238} \mathrm{U} / \mathrm{err}^{207} \mathrm{~Pb} /{ }^{235} \mathrm{U}$. e mean and standard deviation $(2 \sigma)$ of 14 analyses of the Plešovice reference zircon $(338 \pm$ 1 Ma; Sláma et al. 2008).

\section{Discussion}

\subsection{Metamorphic development}

The Altay orogen as a part of Central Asian Orogenic Belt extends from Russia and East Kazakhstan in the west, through Northern China to south-eastern Mongolia in the east. It is composed of Proterozoic to Palaeozoic volcanosedimentary rocks accreted between the Siberian and Tarim continental blocks. The metamorphic rocks in the Mongolian Altay, known only from the Tseel Terrane (Badarch et al. 2002), amalgamated to the SW rim of the Gobi Altay Terrane (see Introduction to this Volume) and the Neoproterozoic metamorphic complex consisting of amphibolite- to granulite-facies metasedimentary and meta-igneous rocks thrusted over the ophiolite in Dariv Range (Dijkstra et al. 2006). In the easternmost Mongolian Altay, three newly described MP-MT metamorphic units - Unegt Uul, Khan Khayrkhan and Chandman Khayrkhan crystalline complexes were tectonically incorporated into geological structures of the Palaeozoic volcanosedimentary complexes of the Gobi-Altay Terrane along its northern margin.

Apparently, despite their close spatial association contrasting metamorphic conditions and geochronological data reveal that the evolution of the three studied crystalline units exhibits distinct features.

The leucogranites and orthogneisses of Unegt Uul Crystalline Complex are exposed in a tectonic mélange along the Cenozoic Bogd fault, with dominating strikeslip component of shearing. There were observed no geological relations with adjacent Palaeozoic rocks. Nevertheless, despite the fact that the granite dating detected two contrasting ages, the studied zircons show no signs of polyphase development or of metamorphic overprint. The leucogranite formation took place at $518 \pm 5 \mathrm{Ma}$, which indicates pre-Variscan evolution and corresponds well with ages of Cambrian granites in the Lake Zone Terrane (Hanžl and Aichler eds. 2007). Significance of the measured ages of $c .377$ Ma remains unclear.

Mineral association in metamorphic rocks of the UUC points to a simple MP-MT event. The P-T conditions in mica schist were estimated to $c .640-660{ }^{\circ} \mathrm{C}$ and 6-6.7 kbar. The metamorphic conditions estimated from amphibolitic rocks correspond to average temperatures of c. $610-760{ }^{\circ} \mathrm{C}$ and pressures of $6.2-7.5 \mathrm{kbar}$.

The exposures of the Chandman Khayrkhan Crystalline Complex are spatially related to the Chandman granite Massif, intrusion of which has been dated at 345 $\pm 2 \mathrm{Ma}$. Although the metamorphic evolution preceding this granite intrusion remains unconstrained, the character of metamorphism (strong migmatitization), together with the geochemical signature of the granitic plutons themselves points to an evolution within the continental crust realm.

The rocks of Khan Khayrkhan Crystalline Complex are systematically exposed in tectonic slices between the unmetamorphosed Lower Carboniferous flysh in the SW and weakly metamorphosed Lower Palaeozoic volcanosedimentary complex in the $\mathrm{N}$. The peak metamorphic assemblage was $\mathrm{Bt}+\mathrm{Ms}+\mathrm{Grt} \pm \mathrm{St} \pm \mathrm{Ky}$ and the calculated conditions correspond to temperatures of $c$. $560-650{ }^{\circ} \mathrm{C}$ and pressures of 7.2-7.4 kbar for the central parts and c. $630-660{ }^{\circ} \mathrm{C}$ and $7.5-7.9 \mathrm{kbar}$ for marginal parts of mineral grains in mica schists. Temperatures of c. $580{ }^{\circ} \mathrm{C}$ and pressures of $6.2 \mathrm{kbar}$ for the central parts 
Tab. 7 LA-ICP-MS U, Pb and Th isotope data of dated zircon grains from sample HO341, Chandman Massif.

\begin{tabular}{|c|c|c|c|c|c|c|c|c|c|c|c|c|c|c|c|c|c|c|}
\hline \multirow[b]{2}{*}{ No. } & \multicolumn{11}{|c|}{ Isotope ratios $^{\mathrm{c}}$} & \multirow[b]{2}{*}{ rho $^{\mathrm{d}}$} & \multicolumn{6}{|c|}{ Ages (Ma) } \\
\hline & $\begin{array}{l}{ }^{207} \mathrm{~Pb}^{\mathrm{a}} \\
\text { (cps) }\end{array}$ & $\begin{array}{c}\mathrm{U}^{\mathrm{b}} \\
(\mathrm{ppm})\end{array}$ & $\begin{array}{c}\mathrm{Pb}^{\mathrm{b}} \\
(\mathrm{ppm})\end{array}$ & $\frac{\mathrm{Th}^{\mathrm{b}}}{\mathrm{U}}$ & $\frac{{ }^{206} \mathrm{~Pb}}{{ }^{204} \mathrm{~Pb}}$ & $\frac{{ }^{206} \mathrm{~Pb}^{*}}{{ }^{238} \mathrm{U}}$ & $\begin{array}{l} \pm 2 \sigma \\
(\%)\end{array}$ & $\frac{{ }^{207} \mathrm{~Pb}^{*}}{{ }^{235} \mathrm{U}}$ & $\begin{array}{c} \pm 2 \sigma \\
(\%)\end{array}$ & $\frac{{ }^{207} \mathrm{~Pb}^{*}}{{ }^{206} \mathrm{~Pb}^{*}}$ & $\begin{array}{l} \pm 2 \sigma \\
(\%)\end{array}$ & & $\frac{{ }^{207} \mathrm{~Pb}}{{ }^{235} \mathrm{U}}$ & $\pm 2 \sigma$ & $\frac{{ }^{206} \mathrm{~Pb}}{{ }^{238} \mathrm{U}}$ & $\pm 2 \sigma$ & $\frac{{ }^{207} \mathrm{~Pb}}{{ }^{206} \mathrm{~Pb}}$ & $\pm 2 \sigma$ \\
\hline \multicolumn{19}{|c|}{ sample HO341 } \\
\hline $\mathrm{zr} 28$ & 3175 & 109 & 7 & 0.63 & 1322 & 0.05547 & 2.0 & 0.3759 & 14 & 0.0492 & 6.8 & 0.14 & 324 & 45 & 348 & 7 & 155 & 319 \\
\hline zr26 & 3469 & 118 & 7 & 0.39 & 7032 & 0.05424 & 2.1 & 0.3930 & 3.9 & 0.0526 & 1.6 & 0.55 & 337 & 13 & 340 & 7 & 310 & 73 \\
\hline zr25 & 94337 & 293 & 39 & 1.00 & 3593 & 0.05423 & 1.8 & 0.3988 & 3.6 & 0.0533 & 1.6 & 0.51 & 341 & 12 & 340 & 6 & 343 & 70 \\
\hline zr26 & 4595 & 157 & 9 & 0.46 & 3941 & 0.05575 & 1.9 & 0.4145 & 3.4 & 0.0539 & 1.4 & 0.55 & 352 & 12 & 350 & 6 & 368 & 64 \\
\hline zr20 & 1572 & 45 & 3 & 0.46 & 2843 & 0.05569 & 2.7 & 0.4073 & 4.5 & 0.0530 & 1.8 & 0.60 & 347 & 16 & 349 & 9 & 331 & 82 \\
\hline zr19 & 6920 & 218 & 13 & 0.70 & 12675 & 0.05432 & 2.4 & 0.3978 & 4.9 & 0.0531 & 2.1 & 0.49 & 340 & 17 & 341 & 8 & 334 & 96 \\
\hline $\mathrm{zr} 18$ & 19926 & 367 & 24 & 0.73 & 488 & 0.05463 & 2.3 & 0.3878 & 4.1 & 0.0515 & 1.7 & 0.55 & 333 & 14 & 343 & 8 & 263 & 78 \\
\hline zr17 & 7120 & 212 & 13 & 0.78 & 7122 & 0.05405 & 2.2 & 0.4022 & 3.2 & 0.0540 & 1.2 & 0.68 & 343 & 11 & 339 & 7 & 369 & 53 \\
\hline zr16 & 11453 & 352 & 20 & 0.61 & 18191 & 0.05188 & 2.0 & 0.3846 & 3.0 & 0.0538 & 1.1 & 0.68 & 330 & 10 & 326 & 7 & 361 & 50 \\
\hline zr14 & 13029 & 261 & 16 & 0.55 & 641 & 0.05532 & 3.3 & 0.3954 & 5.5 & 0.0518 & 2.2 & 0.60 & 338 & 19 & 347 & 12 & 279 & 101 \\
\hline zr11 & 10823 & 320 & 19 & 0.66 & 1905 & 0.05417 & 2.1 & 0.3779 & 6.3 & 0.0506 & 2.9 & 0.34 & 326 & 20 & 340 & 7 & 223 & 136 \\
\hline zr10 & 14243 & 421 & 21 & 0.72 & 2694 & 0.04120 & 4.0 & 0.2992 & 5.3 & 0.0527 & 1.8 & 0.74 & 266 & 14 & 260 & 10 & 315 & 81 \\
\hline $\mathrm{zr} 7$ & 9658 & 292 & 17 & 0.50 & 17693 & 0.05464 & 2.3 & 0.4057 & 3.2 & 0.0539 & 1.1 & 0.72 & 346 & 11 & 343 & 8 & 365 & 49 \\
\hline zr6 & 17020 & & 23 & 0.61 & & & 2.3 & & 6.7 & & 3.2 & & & 23 & 341 & 8 & 349 & 143 \\
\hline zr8 & 7671 & 241 & 14 & 0.51 & 11688 & 0.05400 & 2.1 & 0.4036 & 2.9 & 0.0542 & 1.0 & 0.74 & 344 & 10 & 339 & 7 & 380 & 44 \\
\hline zr3 & 26530 & 447 & 29 & 0.87 & 1005 & 0.05544 & 2.5 & 0.3903 & 8.3 & 0.0511 & 4.0 & 0.30 & 335 & 28 & 348 & 9 & 244 & 183 \\
\hline zr1a & 6152 & 180 & 10 & 0.50 & 10443 & 0.05472 & 3.1 & 0.4100 & 4.3 & 0.0543 & 1.5 & 0.72 & 349 & 15 & 343 & 11 & 385 & 66 \\
\hline $\mathrm{zr} 1 \mathrm{~b}$ & 28833 & 294 & 18 & 0.53 & 749 & 0.05385 & 2.2 & 0.3902 & 3.5 & 0.0526 & 1.4 & 0.61 & 334 & 12 & 338 & 7 & 310 & 64 \\
\hline $\mathrm{zr} 42 \mathrm{a}$ & 24735 & 264 & 16 & 0.48 & 3466 & 0.05671 & 1.9 & 0.4142 & 3.7 & 0.0530 & 1.5 & 0.53 & 352 & 13 & 356 & 7 & 328 & 70 \\
\hline $\mathrm{zr} 42 \mathrm{~b}$ & 12942 & 341 & 21 & 0.44 & 6607 & 0.05692 & 2.0 & 0.4207 & 4.8 & 0.0536 & 2.2 & 0.42 & 357 & 17 & 357 & 7 & 354 & 99 \\
\hline $\mathrm{zr} 42 \mathrm{c}$ & 22104 & 255 & 16 & 0.58 & 841 & 0.05517 & 2.1 & 0.4084 & 4.8 & 0.0537 & 2.2 & 0.43 & 348 & 17 & 346 & 7 & 358 & 97 \\
\hline zr38 & 11954 & 367 & 19 & 0.54 & 4559 & 0.04773 & 2.9 & 0.3557 & 7.0 & 0.0541 & 3.2 & 0.41 & 309 & 21 & 301 & 9 & 374 & 142 \\
\hline zr41 & 10428 & 280 & 15 & 0.50 & 1247 & 0.05075 & 2.5 & 0.3605 & 5.3 & 0.0515 & 2.4 & 0.47 & 313 & 17 & 319 & 8 & 264 & 108 \\
\hline $\mathrm{zr} 40$ & 26694 & 315 & 20 & 0.66 & 961 & 0.05589 & 2.1 & 0.4168 & 3.9 & 0.0541 & 1.7 & 0.53 & 354 & 14 & 351 & 7 & 375 & 75 \\
\hline zr36 & 20469 & 277 & 16 & 0.54 & 1299 & 0.05477 & 2.4 & 0.3988 & 4.6 & 0.0528 & 2.0 & 0.52 & 341 & 16 & 344 & 8 & 321 & 89 \\
\hline zr33 & 18309 & 265 & 15 & 0.43 & 2822 & 0.05384 & 2.0 & 0.4005 & 2.8 & 0.0539 & 1.0 & 0.73 & 342 & 10 & 338 & 7 & 369 & 43 \\
\hline zr31a & 17359 & 218 & 13 & 0.44 & 1072 & 0.05481 & 2.0 & & 4.7 & & 2.1 & 0.43 & 346 & 16 & 344 & 7 & 356 & 95 \\
\hline $\mathrm{zr} 31 \mathrm{~b}$ & 8072 & 256 & 15 & 0.45 & 14737 & 0.05505 & 2.4 & 0.4077 & 3.3 & 0.0537 & 1.2 & 0.71 & 347 & 11 & 345 & 8 & 359 & 52 \\
\hline $\mathrm{zr} 32 \mathrm{a}$ & 32632 & 453 & 27 & 0.51 & 9002 & 0.05602 & 2.3 & 0.4172 & 3.3 & 0.0540 & 1.2 & 0.68 & 354 & 12 & 351 & 8 & 372 & 55 \\
\hline $\mathrm{zr} 32 \mathrm{~b}$ & 26341 & 357 & 21 & 0.59 & 813 & 0.05380 & 2.2 & 0.3963 & 3.7 & 0.0534 & 1.5 & 0.58 & 339 & 13 & 338 & 7 & 347 & 68 \\
\hline zr49 & 49539 & 277 & 17 & 0.72 & 194 & 0.04519 & 4.3 & 0.3293 & 5.1 & 0.0529 & 1.4 & 0.85 & 289 & 15 & 285 & 12 & 322 & 62 \\
\hline zr50 & 6064 & 405 & 17 & 0.65 & 12167 & 0.04382 & 2.8 & 0.3115 & 5.2 & 0.0515 & 2.2 & 0.54 & 275 & 14 & 276 & 8 & 265 & 101 \\
\hline
\end{tabular}

and c. $570-680{ }^{\circ} \mathrm{C}$ and $6.2-6.7 \mathrm{kbar}$ for marginal parts of mineral grains were estimated from amphibolites. This suggests prograde stage of metamorphism during grains growth. This assumption is also in agreement with garnet zoning, whereby the content of Prp increases and Sps decreases from core to rim.

In the late stage of metamorphic development the metamorphosed volcanosedimentary sequence was intruded by a granitic body. The low temperature contrast and, consequently, heat interchange during syn-metamorphic intrusion prevented growth of contact metamorphic minerals. However, the nests of decomposed alumosilicates may be a relict of a former contact-metamorphic mineral assemblage.

Main magmatic event - formation of the granitic protolith to the orthogneiss - corresponded to the lat- est Devonian (363 $\pm 3 \mathrm{Ma})$. In addition, ages of c. 529 and $591 \mathrm{Ma}$ were also obtained in zircon cores from Khan Khayrkhan Crystalline Complex. These may be interpreted as inherited components and point to the presence of pre-Variscan continental crust. Besides the isotopic dating, the palaeontological finds may support the Middle to Late Ordovician age for the sedimentation of the recrystallized limestones in the KKC.

There is some contrast between the chemically relatively evolved granites (slightly metaluminous to peraluminous, medium-K calc-alkaline) of volcanic-arc character and the occurrence of within-plate basalts with tholeiitic affinity and primitive, depleted-mantle like isotopic composition $\left(\varepsilon_{\mathrm{Nd}}^{550}=+8.4,{ }^{87} \mathrm{Sr}^{86} \mathrm{Sr}_{550}=0.7040\right.$, $\left.\mathrm{T}_{\mathrm{Nd}}^{\mathrm{DM}}=0.56 \mathrm{Ga}\right)$. 
Tab. 8 LA-ICP-MS U, Pb and Th isotope data of dated zircon grains from sample RO237, Khan Khayrkhan Crystalline Complex.

\begin{tabular}{|c|c|c|c|c|c|c|c|c|c|c|c|c|c|c|c|c|c|c|}
\hline \multirow[b]{2}{*}{ No. } & \multicolumn{11}{|c|}{ Isotope ratios ${ }^{\mathrm{c}}$} & \multirow[b]{2}{*}{ rho $^{\mathrm{d}}$} & \multicolumn{6}{|c|}{ Ages (Ma) } \\
\hline & $\begin{array}{c}{ }^{207} \mathrm{~Pb}^{\mathrm{a}} \\
(\mathrm{cps})\end{array}$ & $\begin{array}{c}\mathrm{U}^{\mathrm{b}} \\
(\mathrm{ppm})\end{array}$ & $\begin{array}{c}\mathrm{Pb}^{\mathrm{b}} \\
(\mathrm{ppm})\end{array}$ & $\frac{\mathrm{Th}^{\mathrm{b}}}{\mathrm{U}}$ & $\frac{{ }^{206} \mathrm{~Pb}}{{ }^{204} \mathrm{~Pb}}$ & $\frac{{ }^{206} \mathrm{~Pb}^{*}}{{ }^{238} \mathrm{U}}$ & $\begin{array}{l} \pm 2 \sigma \\
(\%)\end{array}$ & $\frac{{ }^{207} \mathrm{~Pb}^{*}}{{ }^{235} \mathrm{U}}$ & $\begin{array}{c} \pm 2 \sigma \\
(\%)\end{array}$ & $\frac{{ }^{207} \mathrm{~Pb}^{*}}{{ }^{206} \mathrm{~Pb}^{*}}$ & $\begin{array}{l} \pm 2 \sigma \\
(\%)\end{array}$ & & $\frac{{ }^{207} \mathrm{~Pb}}{{ }^{235} \mathrm{U}}$ & $\pm 2 \sigma$ & $\frac{{ }^{206} \mathrm{~Pb}}{{ }^{238} \mathrm{U}}$ & $\pm 2 \sigma$ & $\frac{{ }^{207} \mathrm{~Pb}}{{ }^{206} \mathrm{~Pb}}$ & $\pm 2 \sigma$ \\
\hline \multicolumn{19}{|c|}{ sample RO237 } \\
\hline zr6 & 133059 & 1336 & 93 & 0.41 & 182 & 0.0510 & 1.7 & 0.3751 & 3.5 & 0.0533 & 3.0 & 0.49 & 323 & 11 & 321 & 5 & 342 & 69 \\
\hline $\mathrm{zr} 7$ & 7732 & 265 & 16 & 0.68 & 12128 & 0.0535 & 2.8 & 0.3957 & 5.3 & 0.0537 & 4.4 & 0.54 & 339 & 18 & 336 & 10 & 357 & 100 \\
\hline zr35 & 12676 & 242 & 14 & 0.63 & 631 & 0.0469 & 4.1 & 0.3507 & 6.4 & 0.0542 & 4.9 & 0.64 & 305 & 20 & 296 & 12 & 380 & 111 \\
\hline zr14 & 421031 & 1450 & 136 & 1.00 & 51 & 0.0252 & 6.4 & 0.1887 & 7.7 & 0.0544 & 4.3 & 0.83 & 176 & 14 & 160 & 10 & 388 & 97 \\
\hline $\mathrm{zr} 15 \mathrm{a}$ & 20099 & 20 & 24 & 0.65 & 217 & 0.0482 & 1.8 & 0.3473 & 5.9 & 0.0523 & 5.6 & 0.31 & 303 & 18 & 303 & 6 & 298 & 128 \\
\hline $\mathrm{zr} 15 \mathrm{~b}$ & 302113 & 1631 & 137 & 0.85 & 88 & 0.0419 & 2.3 & 0.2947 & 6.4 & 0.0510 & 6.0 & 0.36 & 262 & 17 & 264 & 6 & 243 & 139 \\
\hline zr12 & 621753 & 1981 & 211 & 0.72 & 158 & 0.0332 & 2.0 & 0.2402 & 4.4 & 0.0526 & 4.0 & 0.46 & 219 & 10 & 210 & 4 & 310 & 90 \\
\hline zr18 & 74553 & 868 & 54 & 0.56 & 287 & 0.0515 & 1.8 & 0.3876 & 3.5 & 0.0546 & 3.0 & 0.52 & 333 & 12 & 324 & 6 & 395 & 67 \\
\hline $\mathrm{zr} 19 \mathrm{a}$ & 19487 & 628 & 37 & 0.38 & 34269 & 0.0583 & 1.9 & 0.4345 & 2.4 & 0.0541 & 1.5 & 0.77 & 366 & 9 & 365 & 7 & 374 & 35 \\
\hline zr19b & 6008 & 186 & 11 & 0.38 & 9994 & 0.0591 & 1.8 & 0.4391 & 3.1 & 0.0538 & 2.5 & 0.57 & 370 & 11 & 370 & 7 & 365 & 57 \\
\hline zr20 & 218534 & 1487 & 106 & 0.57 & 129 & 0.0389 & 1.9 & 0.2841 & 3.2 & 0.0529 & 2.5 & 0.59 & 254 & 8 & 246 & 5 & 324 & 58 \\
\hline zr27 & 3230 & 116 & 8 & 0.98 & 6789 & 0.0565 & 2.2 & 0.4143 & 3.7 & 0.0532 & 3.0 & 0. & 352 & 13 & 354 & 8 & 338 & 67 \\
\hline $\mathrm{zr} 28$ & 466679 & 472 & 140 & 0.66 & 128 & 0.0584 & 2.7 & 0.4288 & 3.9 & 0.0532 & 2.8 & 0.69 & 362 & 14 & 366 & 10 & 339 & 65 \\
\hline zr29 & 6864 & 152 & 15 & 0.72 & 11295 & 0.0855 & 1.8 & 0.6889 & 2.5 & 0.0584 & 1.8 & 0.7 & 532 & 13 & 529 & 9 & 546 & 39 \\
\hline $\mathrm{zr} 30$ & 11169 & 319 & 21 & 0.74 & 1259 & 0.0582 & 1.8 & 0.4361 & 3.8 & 0.0543 & 3.3 & 0.46 & 367 & 14 & 365 & 6 & 384 & 75 \\
\hline zr31 & 11659 & 406 & 24 & 0.43 & 19515 & 0.0563 & 2.0 & 0.4205 & 3.1 & 0.0541 & 2.3 & 0.67 & 356 & 11 & 353 & 7 & 377 & 51 \\
\hline zr32 & 123561 & 1349 & 81 & 0.61 & 526 & 0.0404 & 4.4 & 0.3020 & 7.3 & 0.0542 & 5.8 & 0.61 & 268 & 19 & 255 & 11 & 380 & 130 \\
\hline zr33 & 14379 & 298 & 20 & 0.59 & 15780 & 0.0579 & 2.5 & 0.4282 & 3.1 & 0.0536 & 1.9 & 0.79 & 362 & 11 & 363 & 9 & 354 & 44 \\
\hline $\mathrm{zr} 1$ & 12890 & 237 & 26 & 0.88 & 19940 & 0.0960 & 1.7 & 0.7931 & 2.4 & 0.0599 & 1.7 & 0.70 & 593 & 14 & 591 & 10 & 600 & 38 \\
\hline $\mathrm{zr} 2$ & 226195 & 900 & 100 & 0.48 & 155 & 0.0532 & 3.5 & 0.3822 & 7.4 & 0.0521 & 6.5 & 0.47 & 329 & 24 & 334 & 12 & 289 & 149 \\
\hline zr8 & 19892 & 1196 & 48 & 0.54 & 182 & 0.0340 & 4.4 & 0.2519 & 6.2 & 0.0538 & 4.5 & 0.70 & 228 & 14 & 215 & 9 & 362 & 101 \\
\hline $\mathrm{zr} 9$ & 98063 & 1010 & 67 & 0.65 & 223 & 0.0462 & 3.2 & 0.3351 & 6.4 & 0.0526 & 5.6 & 0.50 & 293 & 19 & 291 & 9 & 310 & 127 \\
\hline $\mathrm{zr} 23$ & 52193 & 706 & 39 & 0.87 & 202 & 0.0374 & 3.8 & 0.2903 & 6.0 & 0.0562 & 4.6 & 0.63 & 259 & 15 & 237 & 9 & 462 & 102 \\
\hline $\mathrm{zr} 24$ & 5008 & 176 & 11 & 0.79 & 7606 & 0.0567 & 1.8 & 0.4242 & 3.4 & 0.0543 & 2.9 & 0.53 & 359 & 12 & 355 & 6 & 382 & 66 \\
\hline zr26 & 3260 & 98 & 6 & 0.34 & 3861 & 0.0584 & 1.9 & 0.4261 & 4.8 & 0.0529 & 4.4 & 0.39 & 360 & 17 & 366 & 7 & 324 & 99 \\
\hline $\mathrm{zr} 4$ & 35499 & 604 & 38 & 0.48 & 8021 & 0.0589 & 1.8 & 0.4418 & 3.3 & 0.0544 & 2.8 & 0.53 & 372 & 12 & 369 & 6 & 386 & 63 \\
\hline
\end{tabular}

Tab. 9 Summarized LA-ICP-MS U, Pb and Th isotope ages from Unegt Uul Crystalline Complex, Chandman Massif and Khan Khayrkhan Crystalline Complex.

\begin{tabular}{llllllll}
\hline sample & rock & unit & LI (Ma) & UI (Ma) & AVG (Ma) & map (Ma) & dated event \\
\hline H0057 & granite & UUC & & $329 \pm 33$ & $336 \pm 6.0$ & 330 & $?$ \\
H0057 & granite & UUC & & & $518 \pm 5.0$ & 518 & granite crystallization \\
H0341 & granodiorite & GCH & $154 \pm 160$ & $354 \pm 26$ & $344 \pm 1.9$ & 345 & granite emplacement \\
R0237 & orthogneiss & KKC & $160+57 /-61$ & $362+17 /-16$ & $363 \pm 3.1$ & 363 & granite emplacement \\
R0237 & orthogneiss & KKC & & $529 \pm 9$ & $529 \pm 9$ & 530 & inheritance \\
R0237 & orthogneiss & KKC & & $591 \pm 10$ & $591 \pm 10$ & & inheritance \\
\hline
\end{tabular}

\subsection{Geological interpretation}

The southern domains of Mongolia are represented by the Silurian to Carboniferous accretionary complexes and arc-related volcanoclastic rocks (Lamb and Badarch 1997). This characteristic can be also applied to the Gobi-Altay Terrane in the Chandman area. The whole sequence is built by very low grade Ordovician to Devonian sedimentary-volcanosedimentary complex representing relatively deep-basin sediments. This Or- dovician and Silurian sedimentation was characterized by an episodic influx of clastic and bioclastic material to the basins towards the Devonian and Carboniferous (Hanžl and Aichler 2007). Within these sedimentary sequences are tectonically incorporated crystalline units of different lithological and metamorphic character. The whole assemblage was intruded by Variscan granitoid rocks of I-type (CHC) and S-type (KKC) affinity during a relatively short time interval between 363 and $354 \mathrm{Ma}$, respectively $332 \mathrm{Ma}$. 
The spatial and temporal relations suggest the contemporary evolution of the Chandman Khayrkhan and Khan Khayrkhan crystalline units in Late Palaeozoic. However, their position in the frame of orogenic belt was different. The intrusion of the protolith to the Khan Khayrkhan orthogneisses was probably related to an earlier phase of Variscan metamorphism in a volcanic-arc environment. The emplacement of the Chandman Massif followed the peak of Variscan metamorphism in the frame of accretion (collision) of an evolved volcanic arc or a microcontinent.

Both units were accreted together with the Palaeozoic sequences between the Lake Zone Terrane in the $\mathrm{N}$ and Tseel Terrane in the $\mathrm{S}$. The more precise interpretation is hampered by Cenozoic imbrication in restraining bends evolved in the Northern Gobi-Altay fault zone.

Noticeable is the temporal (and partly lithologic) analogy with the Tseel Terrane (see Introduction to this Volume). The Tseel Terrane is a complex of Early Devonian volcanic-arc rocks with zircon age of $c$. 400 Ma that were subsequently metamorphosed to amphibolite-facies migmatitic amphibolites and gneisses (Windley et al. 2007). The zircon age from gneisses corresponds to $360.5 \pm 1.1$ $\mathrm{Ma}$ and the Tseel Terrane is interpreted as the root of an arc system (Kröner et al. 2007).

The Unegt Uul Crystalline Complex has a lithologic character as well as a metamorphic and structural evolution completely different from the remaining two units. Geochemical characteristics with geochronological data resemble closely the Burdnii Gol Massif (Hanžl et al. 2007), which belongs to the Lake Zone Terrane. Consequently, the Unegt Uul Crystalline Complex may also show a genetic link to the Lake Zone Terrane and be independent of the Gobi-Altay Terrain. Instead it may represent a rock slice incorporated into the Gobi-Altay Zone tectonically along the Bogd fault.

\section{Conclusions}

Metamorphic domains exposed in tectonic slices among the Palaeozoic volcanosedimentary sequences were newly described in the Gichigeney Nuruu Mountains (eastern Mongolian Altay) and Unegt Uul range (western Gobi Altay). The area is situated along the northern margin of the Gobi Altay Terrane, close to boundary with the Lake Zone Terrane. Unegt Uul, Chandman Khayrkhan and Khan Khayrkhan crystalline complexes were defined on the basis of distinct geological position, lithology, metamorphic conditions and age.

Unegt Uul Crystalline Complex represents a tectonic mélange closely associated with the Bogd Fault system. The Complex consists of prevailing granites to leucogranites with mica schists representing the roof pendants of the granitic intrusions and tectonically assembled fragments of basic rocks. The metamorphic conditions estimated for the amphibolites correspond to $c .610{ }^{\circ} \mathrm{C}$ and $6 \mathrm{kbar}$ in the cores and $c .650-760{ }^{\circ} \mathrm{C}$ and $6-7 \mathrm{kbar}$ in the marginal parts of the mineral grains. Mica schists yielded $\mathrm{T}=c .640-660^{\circ} \mathrm{C}$ and $\mathrm{P}=6.0-6.7 \mathrm{kbar}$.

Chandman Khayrkhan Crystalline Complex is a metamorphic unit markedly affected by the Chandman granite intrusion. It is represented by orthogneisses and migmatites with lenses of amphibolite and sporadic calc-silicate bodies. The metamorphic development featured a HT event with subsequent retrogression under amphibolite-facies conditions perceptible from the mineral association of the calc-silicate rocks. The monotonous mineral assemblages of the rocks hamper any more specific determination of the $\mathrm{P}-\mathrm{T}$ metamorphic conditions.

Khan Khayrkhan Crystalline Complex is a narrow tectonic slice sandwiched in between the Lower and Upper Palaeozoic sedimentary sequences represented by orthogneisses with lenses and layers of amphibolites, mica schists, paragneisses and recrystallized limestones. The $\mathrm{P}-\mathrm{T}$ conditions correspond to $c .560-650^{\circ} \mathrm{C}$ and $6.2-7.4$ kbar for the central parts and c. $630-680^{\circ} \mathrm{C}, 6.4-8 \mathrm{kbar}$ for marginal parts of mineral grains.

Laser ablation ICP-MS U-Pb dating suggests a formation of the UUC leucogranites at c. $518 \mathrm{Ma}$. Intrusion of granitic protolith to the KKC orthogneiss took place at $363 \pm 3 \mathrm{Ma}$, while inherited zircon cores point to earlier zircon crystallization events at $c .529$ and $591 \mathrm{Ma}$. The rocks of $\mathrm{CHC}$ remain undated, the only time information having been provided by dating of the Chandman Massif granites themselves $(345 \pm 2 \mathrm{Ma})$. These data confirm the Variscan tectonometamorphic activity inside the Gobi-Altay and Lake Zone terranes in the Southern Domain of Mongolia.

Acknowledgements. The presented data have been gathered within the framework of the project Zamtyn Nuruu-50 funded by the International Development Cooperation of the Czech Republic. It could not materialize without neither the logistic support by J. Holák a Z. Novotný for the technical background provided by Mongolian drivers and students. We are indebted to V. Erban from the Radiogenic Isotopes Lab of the Czech Geological Survey, who acquired the $\mathrm{Sr}-\mathrm{Nd}$ isotopic data and to R. Čopjaková with R. Škoda from the Joint Electron Microanalysis Laboratory of the Masaryk University and the Czech Geological Survey in Brno, who were responsible for microprobe analysis and CHIME monazite dating. We are also grateful to M. Janák and A. Proyer for helpful reviews. Last but not least, the careful editorial handling by W. S. Faryad helped us to improve significantly the ideas expressed in this text. 
Electronic supplementary material. The Tabs 1-2, as well as GPS coordinates of the studied samples, are available online at the Journal web site (http://dx.doi.org/10.3190/ jgeosci.027).

\section{References}

BADARCH G, TOMURTOGOO O (2001) Tectonostratigraphic Terranes of Mongolia. Gondwana Research 4: 143-144

Badarch G, Cunningham WD, Windley BF (2002) A new terrane subdivision for Mongolia: implications for the Phanerozoic crustal growth of central Asia. J Asian Earth Sci 20: 87-100

Baljinnyam I, Bayasgalan A, Borisov BA, Cisternas A, Dem'yanovich MG, Ganbaatar L, Kochetkov VM, KuRushin RA, Molnar P, Philip H, Vashchilov YY (1993) Ruptures of major earthquakes and active deformation in Mongolia and its surroundings: Geol Soc Am Memoir 181: pp 1-62

Bayasgalan A (1999) Active tectonics of Mongolia. Unpublished $\mathrm{PhD}$. Thesis, Trinity College Cambridge, $\mathrm{pp}$ $1-180$

Batchelor RA, Bowden P (1985) Petrogenetic interpretation of granitoid rock series using multicationic parameters. Chem Geol 48: 43-55

Bhattacharya A, Mohanty L, Maji A, Sen SK, Raith M (1992) Non-ideal mixing in the phlogopite-annite binary: constraints from experimental data on $\mathrm{Fe}-\mathrm{Mg}$ partitioning and a reformulation of the biotite-garnet thermometer. Contrib Mineral Petrol 111: 87-93

BOYNTON WV (1984) Cosmochemistry of the rare earth elements: meteorite studies. In: Henderson P (ed) Rare Earth Element Geochemistry. Elsevier, Amsterdam, pp 63-114

Buchan C, Pfander J, KRöner A (2002) Timing of accretion and collisional deformation in the Central Asian Orogenic Belt: implications of granite geochronology in the Bayankhongor ophiolite zone. Chem Geol 192: 23-45

BuRiáNEK D, HANŽL P, HRdLIČKová K (in press) Tourmaline in migmatites, pegmatites and quartz veins of the Chandman Massif (Gobi Altay, Western Mongolia), example of fractionation of anatectic melt. Mongolian Geoscientist

Cunningham WD, Dijkstra A, Howard J, Quarles A, BADARCH G (2003) Active intraplate strike-slip faulting and transpressional uplift in the Mongolian Altai. In: Storti F, Holdsworth RE, Salvini F (eds) Intraplate Strike-slip Deformation Belts. Geol Soc London Spec Pub 210: pp 65-87

Dergunov AB (ed) (2001) Tectonics, Magmatism, and Metallogeny of Mongolia. Routledge, London, pp $1-288$

Dijkstra AH, Brouwer FM, Cunningham WD, Buchan C, Badarch G, Mason PRD (2006) Late Neoproterozoic proto-arc ocean crust in the Dariv Range, Western Mongolia: a supra-subduction zone end-member ophiolite. J Geol Soc, London 163: 363-373

Economos R, Hanžl p, HrdličKová K, BuRiánek D, SAid LO, Gerdes A (in press) Geochemical and structural constraints on the magmatic history of the Chandman Massif of the eastern Mongolian Altay Range, SW Mongolia. J Geosci

FERRY JM, SPEAR FS (1978) Experimental calibration of the partitioning of $\mathrm{Fe}$ and $\mathrm{Mg}$ between biotite and garnet. Year Book - Carnegie Institution of Washington 76: 579-581

Gerdes A, Zeh A (2006) Combined U-Pb and Hf isotope LA(MC-) ICP-MS analyses of detrital zircons: comparison with SHRIMP and new constraints for the provenance and age of an Armorican metasediment in Central Germany. Earth Planet Sci Lett 249: 47-62

Gerdes A, Zeh A (2008) Zircon formation versus zircon alteration - new insights from combined $\mathrm{U}-\mathrm{Pb}$ and Lu-Hf in-situ La-ICP-MS analyses of Archean zircons from the Limpopo Belt. Chem Geol, doi 10.1016/ j.chemgeo.2008.03.005

GuidotTI CV (1984) Micas in metamorphic rocks. In: BAILEY SW (ed) Micas. Mineralogical Society of America and Geochemical Society Reviews in Mineralogy and Geochemistry 13, Washington, pp 357-467

Hanžl p, Buriánek D, HrdličKová K, Aichler J, Gerdes A, ByAmbasuren D (2007) Granitoid massifs of the Zamtyn Nuruu area, SW Mongolia. In: BREITER K (ed) Proceedings of the $3^{\text {rd }}$ Meeting of the Czech Geological Society, Volary, 19-22 September 2007, pp 27 (in Czech)

HANŽL P, Aichler J (eds) (2007) Geological Survey of the Mongolian Altay at a scale 1:50,000 (Zamtyn Nuruu -50), Final Report, pp 1-389

Helo C, Hegner E, Kröner A, Badarch G, Tomurtogoo O, Windley BF, Dulski P (2006) Geochemical signature of Paleozoic accretionary complexes of the Central Asian Orogenic Belt in South Mongolia: constraints on arc environments and crustal growth. Chem Geol 227: 236-257

Holland TJB, Powell R (1985) An internally consistent thermodynamic dataset with uncertainties and correlations: 2. Data and results. J Metamorph Geol 3: 343-370

Holland TJB, Powell R (1998) An internally consistent thermodynamic data set for phases of petrological interest. J Metamorph Geol 16: 309-343

JaCobSen SB, WasSerburG GJ (1980) Sm-Nd isotopic evolution of chondrites. Earth Planet Sci Lett 50: 139-155

Jahn BM, Capdevila R, Liu D, Vernon A, Badarch G (2004) Sources of Phanerozoic granitoids in the transect Bayanhongor-Ulaan Baatar, Mongolia: geochemical and $\mathrm{Nd}$ isotopic evidence, and implications for Phanerozoic crustal growth. J Asian Earth Sci 23: 629-653 
Kepezhinskas PK, Kepezhinskas KB, Pukhtel IS (1991) Lower Paleozoic oceanic crust in Mongolian Caledonides; Sm-Nd isotope and trace element data. Geophys Res Lett 18: 1301-1304

Khain EV, Bibikova EV, Kröner A, Zhuravlev DZ, Sklyarov EV, Fedotova AA, Kravchenko-Berezhnoy IR (2002) The most ancient ophiolite of the Central Asian fold belt: $\mathrm{U}-\mathrm{Pb}$ and $\mathrm{Pb}-\mathrm{Pb}$ zircon ages for the Dunzhugur Complex, Eastern Sayan, Siberia, and geodynamic implications. Earth Planet Sci Lett 199: 311-325

Khain EV, Bibikova EV, Salnikova EB, Kröner A, Gibsher AS, Didenko AN, Degtyarev KE, Fedotova AA (2003) The Palaeo-Asian ocean in the Neoproterozoic and Early Palaeozoic: new geochronologic data and palaeotectonic reconstructions. Precambr Res 122: 329-358

Kovach VP, Jian P, Yarmolyuk VV (2005) Magmatism and geodynamics of early stages of the Paleoasian ocean formation: geochronological and geochemical data on ophiolites of the Bayan-Khongor zone. J Earth Sci 404: 1072-1077

Kozakov IK, Liu D, Terenteva LB, Lebedev VI, Kovalenko VI (2005) Magmatism and geodynamics of early stages of the Paleoasian Ocean formation: geochronological and geochemical data on ophiolites of the Bayan-Khongor Zone. J Earth Sci 404: 1072-1077

Kröner A, Windley BF, Badarch G, Tomurtogoo O, Hegner E, Jahn BM, Gruschka S, Khain EV, Demoux A, Wingate MTD (2007). Accretionary growth and crust-formation in the Central Asian Orogenic Belt and comparison with the Arabian-Nubian shield. In: HATCHER RD JR, Carlson MP, McBride JH, Martínez Catalán JR (eds), 4-D Framework of Continental Crust. Geol Soc Am Memoir 200: pp 181-209.

LAMB MA, BADARCH G (1997) Paleozoic sedimentary basins and volcanic-arc systems of southern Mongolia: new stratigraphic and sedimentologic constraints. Int Geol Rev 39: 542-576

Leake BE, Woolley AR, Arps CES, Birch WD, Gilbert MC, Grice JD, Hawthorne FC, Kato A, Kisch HJ, KrivoviCheV VG, Linthout K, Laird J, Mandarino JA, Maresch WV, Nickel EH, Rock NMS, Schumacher JC, SMith DC, Stephenson NCN, Ungaretti L, Whittaker EJW, Youshi G (1997) Nomenclature of amphiboles: report of the Subcommittee on amphiboles of the International Mineralogical Association, Commission on new minerals and mineral names. Amer Miner 82: 1019-1037

Lee SM, Holdaway MJ (1977) Significance of Fe-Mg cordierite stability relations on temperature, pressure, and water pressure in cordierite granulites. In: Heacock JG (ed) The Earth's Crust; Its Nature and Physical Properties. Geophys Monograph 20, AGU Washington pp 79-94

Liew TC, Hofmann AW (1988) Precambrian crustal components, plutonic associations, plate environment of the Hercynian Fold Belt of Central Europe: indications from a $\mathrm{Nd}$ and $\mathrm{Sr}$ isotopic study. Contrib Mineral Petrol 98: $129-138$

Lugmair GW, Marti K (1978) Lunar initial ${ }^{143} \mathrm{Nd} /{ }^{144} \mathrm{Nd}$ : differential evolution line of the lunar crust and mantle. Earth Planet Sci Lett 39: 349-357

Maniar PD, Piccoli PM (1989) Tectonic discrimination of granitoids. Geol Soc Am Bull 101: 635-643

Marinov NA, Zonenshain LP, Blagonravov VA (eds) (1973) Geologija Mongolskoi narodnoi respubliky. Nedra, Moscow, pp 1-582 (in Russian)

Meschede M (1986) A method of discriminating between different types of mid-ocean ridge basalts and continental tholeiites with the $\mathrm{Nb}-\mathrm{Zr}-\mathrm{Y}$ diagram. Chem Geol 56: 207-218

MielKe P, WinKLeR HGF (1979) Eine bessere Berechnung der Mesonorm für granitische Gesteine. Neu Jb Mineral, Mh 471-480

Míková J, Denková P. (2007) Modified chromatographic separation scheme for $\mathrm{Sr}$ and $\mathrm{Nd}$ isotope analysis in geological silicate samples. J Geosci 52: 221-226

Molnar P, TapPonnier P (1975) Cenozoic tectonics of Asia: effects of a continental collision: features of recent continental tectonics in Asia can be interpreted as results of the India-Eurasia collision. Science 189: 419-426

Montel JM, Foret S, Veschambre M, Nicollet C, Provost A (1996) Electron microprobe dating of monazite. Chem Geol 131: 37-53

Mossakovsky AA, Ruzhentsev SV, Samygin SG, KHERASKOVA TN (1994) Central Asian fold belt; geodynamic evolution and formation history. Geotectonics 27: 445-474.

Pearce JA, Harris NW, Tindle AG (1984) Trace element discrimination diagrams for the tectonic interpretation of granitic rocks. J Petrol 25: 956-983

Peccerillo A, Taylor SR (1976) Geochemistry of Eocene calc-alkaline volcanic rocks from the Kastamonu area, Northern Turkey. Contrib Mineral Petrol 58: 63-81

Perchuk LL, Lavrenteva IV (1983) Experimental investigation of exchange equilibria in the system cordieritegarnet-biotite. In: SAXENA SK (ed) Kinetics and Equilibrium in Mineral Reactions. Springer-Verlag, Berlin, pp 199-239

Pin C, Zalduegui JFS (1997) Sequential separation of light rare-earth elements, thorium and uranium by miniaturized extraction chromatography: application to isotopic analyses of silicate rocks. Anal Chim Acta 339: 79-89

Pin C, Briot D, Bassin C, Poitrasson F (1994) Concomitant separation of strontium and samarium-neodymium for isotopic analysis in silicate samples, based on specific extraction chromatography. Anal Chim Acta 298: 209-217

Powell R, Holland TJB (1985) An internally consistent thermodynamic dataset with uncertainties and correla- 
tions: 1. Method and a worked example, J Metamorph Geol 3: 327-342

Rauzer AA, Zhanchiv DI, Golyakov VI, Ykhina IF, IVANOv IG, Tsukernik AB, Afonin VV, Smirnov IG, Bykhover VI, Kravtsev AV, Baatarkhuyag A, Skoryukin MI, Khodikov IV, Mantsev NV, Okaemov SV, Mischin VA, ENKHSAJKHAN T (1987) Report on results of geological mapping on scale 1:200,000 in the south-western part of Mongolian Altay in 1983-1986, Mongolian National Republic. Tekhnoexport, Moscow, pp 1-352 (in Russian)

RAVNA EK (2000) Distribution of $\mathrm{Fe}^{2+}$ and $\mathrm{Mg}$ between coexisting garnet and hornblende in synthetic and natural systems: an empirical calibration of the garnet-hornblende $\mathrm{Fe}-\mathrm{Mg}$ geothermometer. Lithos 53: 265-277

Sengör AC, Natalin BA, Burtman VS (1993) Evolution of the Altaid tectonic collage and Paleozoic crustal growth in Eurasia. Nature 364: 299-306

Shand SJ (1943) Eruptive Rocks. Their Genesis, Composition, Classification, and Their Relation to Ore-Deposits with a Chapter on Meteorite. $2^{\text {nd }}$ Edition. John Wiley \& Sons, New York, pp 1-444

Sláma J, Košler J, Condon D J, Crowley J L, Gerdes A, Hanchar J M, Horstwood M S A, Morris G A, Nasdala L, Norberg N, Schaltegger U, Schoene B, Tubrett M N, Whitehouse M J (2008) Plešovice zircon - a new natural reference material for $\mathrm{U}-\mathrm{Pb}$ and $\mathrm{Hf}$ isotopic microanalysis. Chem Geol 249: 1-35

Stacey J, Kramers J (1975) Approximation of terrestrial lead isotope evaluation by a two-stage model. Earth Planet Sci Lett 26: 207-221

Steiger RH, JäGer E (1977) Subcommission on Geochronology; convention on the use of decay constants in geo- and cosmochronology. Earth Planet Sci Lett 36: 359-362

Streckeisen A, Le Maitre RW (1979) A chemical approximation to the modal QAPF classification of the igneous rocks. Neu Jb Mineral, Abh 136: 169-206
Sun SS, McDonough WF (1989) Chemical and isotopic systematics of oceanic basalts: implications for mantle composition and processes. In: SAUNDERS AD, NORRY MJ (eds) Magmatism in Ocean Basins. Geol Soc London Spec Pub 42: pp 313-345

THOMPSON AB (1976) Mineral reactions in pelitic rocks: II. Calculation of some P-T-X (Fe-Mg) phase relations. Amer J Sci 276: 425-454

THOMPSON JB JR, NoRTon SA (1968) Paleozoic regional metamorphism in New England and adjacent areas. In: Zen E, White WS, Hadley JB, Thompson JB (eds) Studies of Appalachian Geology, Northern and Maritime. Interscience Publishers, New York, pp 319-327

TrACY RJ (1982) Compositional zoning and inclusions in metamorphic minerals. In: FERRY JM (ed) Characterization of Metamorphism Through Mineral Equilibria. Rev Mineral Geochem 10: 355-397

Vassallo R, Ritz J, Braucher R, Jolivet M, Carretier S, Larroque C, Chauvet A, Sue C, Todbileg M, Bourles D (2007) Transpressional tectonics and stream terraces of the Gobi-Altay, Mongolia. Tectonics 26, TC5013, doi:10.1029/2006TC002081.

Windley BF, Kröner A, Guo J, Qu G, Li Y, Zhang C (2002) Neoproterozoic to Paleozoic geology of the Altai orogen, NW China: new zircon age data and tectonic evolution. J Geol 110: 719-737

Windley BF, Dmitriy A, Wenjiao X, Kröner A, Badarch G (2007) Tectonic models for accretion of the Central Asian Orogenic Belt. J Geol Soc, London 164: 31-47

Xiao XC, Tang YQ, Feng YM, Zhu BQ, Li JY, Zhao M (1992) In: Tectonic Evolution of the Northern Xinjiang and Its Adjacent Region, Geological Publishing House, Beijing (1992), pp 1-180 (in Chinese, with English abstract)

Yarmolyuk VV, Kovalenko VJ (2001) Middle Palaeozoic continental margin magmatism of Mongolia. In: DERGUNOv AB (ed) Tectonics, Magmatism, and Metallogeny of Mongolia. Routledge, London, pp 95-127 